\title{
Licorice (Glycyrrhiza glabra) Extracts-Suitable Pharmacological Interventions for COVID-19? A Review
}

\author{
Joji Abraham ${ }^{1, *}$ and Singarayer Florentine ${ }^{2}$ (D) \\ 1 School of Engineering, Information Technology, and Physical Sciences, Mt Helen Campus, Federation \\ University Australia, Ballarat, VIC 3353, Australia \\ 2 Centre for Environmental Management, School of Science, Psychology, and Sport, Mt Helen Campus, \\ Federation University Australia, Ballarat, VIC 3353, Australia; s.florentine@federation.edu.au \\ * Correspondence: J.abraham@federation.edu.au; Tel.: +61-412-751-134
}

Citation: Abraham, J.; Florentine, S.

Licorice (Glycyrrhiza glabra)

Extracts-Suitable Pharmacological Interventions for COVID-19? A

Review. Plants 2021, 10, 2600

https://doi.org/10.3390/

plants10122600

Academic Editor: Suresh Awale

Received: 30 August 2021

Accepted: 23 November 2021

Published: 26 November 2021

Publisher's Note: MDPI stays neutral with regard to jurisdictional claims in published maps and institutional affiliations.

Copyright: (c) 2021 by the authors. Licensee MDPI, Basel, Switzerland. This article is an open access article distributed under the terms and conditions of the Creative Commons Attribution (CC BY) license (https:// creativecommons.org/licenses/by/ $4.0 /)$.

\begin{abstract}
Even though vaccination has started against COVID-19, people should continue maintaining personal and social caution as it takes months or years to get everyone vaccinated, and we are not sure how long the vaccine remains efficacious. In order to contribute to the mitigation of COVID-19 symptoms, the pharmaceutical industry aims to develop antiviral drugs to inhibit the SARS-CoV-2 replication and produce anti-inflammatory medications that will inhibit the acute respiratory distress syndrome (ARDS), which is the primary cause of mortality among the COVID-19 patients. In reference to these tasks, this article considers the properties of a medicinal plant named licorice (Glycyrrhiza glabra), whose phytochemicals have shown both antiviral and anti-inflammatory tendencies through previous studies. All the literature was selected through extensive search in various databases such as google scholar, Scopus, the Web of Science, and PubMed. In addition to the antiviral and anti-inflammatory properties, one of the licorice components has an autophagyenhancing mechanism that studies have suggested to be necessary for COVID-19 treatment. Based on reviewing relevant professional and historical literature regarding the medicinal properties of licorice, it is suggested that it may be worthwhile to conduct in vitro and in vivo studies, including clinical trials with glycyrrhizic and glycyrrhetinic acids together with other flavonoids found in licorice, as there is the potentiality to provide natural interventions against COVID-19 symptoms.
\end{abstract}

Keywords: ARDS; antiviral drug; anti-inflammatory drug; coronavirus; glycyrrhizic acid; glycyrrhetinic acid; medicinal plants; SARS-CoV-2 pandemic

\section{Introduction}

The coronavirus disease (COVID-19), which began in the city of Wuhan in the Peoples' Republic of China (PRC) during the last quarter of 2019, quickly moved to Europe and the USA and subsequently into the Asian and African countries. This severe acute respiratory syndrome coronavirus-2 (SARS-CoV-2) has now infected millions of people worldwide and has taken more than 5 million lives as of the end of October 2021 [1]. At the time of writing (October 2021), no pharmaceutical intervention was developed to treat COVID19 symptoms, specifically ARDS, but vaccination has been quickly going on in various parts of the world. Although most countries are providing vaccines to their citizens as quickly as possible, hundreds of thousands of breakthrough cases are reported from all around the world, specifically from India and Israel [2-10]. As it may take several months or years to vaccinate all the people worldwide, many countries still follow curfews and lockdown measures, which clearly affect personal freedoms and impinge heavily on economic progress. Even after a year of starting, tens of thousands of business offices have been closed, with staff working from their home environment. Apart from this, hundreds of thousands of schools, colleges, and universities across the world have been closed, with students forced to learn online. As a result of these disruptions, many people struggle to find income to support their families, and several national and state governments have been 
required to ensure sufficient revenue flow within their communities. This situation will only be relieved with the development and availability of symptomatic control medicines or by vaccinating the whole world against all the existing and potential strains. The presence of hundreds of thousands of breakthrough cases highlights the significance of pharmacological interventions to treat COVID-19 cases.

The severe symptoms which affect individuals suffering from COVID-19 have been termed 'Acute respiratory distress syndrome (ARDS)' and include severe inflammation of the lungs, blood clots, and multi-organ failures [11]. Studies have also found lymphopenia with T-cell hyperactivation, leukopenia, and thrombocytopenia among $40 \%$ of the affected patients [12]. It has been claimed that the formation of cytokine storms in the body and depositions in the lung alveoli related to the viral clearance mechanisms is considered responsible for the severity of the condition and the need for hospitalization [12,13]. Further, the presence of ferritin and interleukin-6 (IL-6) are considered to be potential biomarkers in predicting mortality, strengthening the conviction that hyper inflammation is responsible for patient hospitalization, which often requires intensive ventilation [12]. It would thus appear that if any pharmaceutical intervention can prevent viral replication in the body (antiviral property) and inhibit severe lung inflammation (anti-inflammatory property), many lives can be saved from COVID-19 infection.

It is well known that inflammation is a physio-pathological condition characterized by the body's complex biological response to physical, chemical, and biological stimuli. It is an adaptive response, which is triggered by injuries or pathogen invasions in the body. In the modern medical system, several antiviral and anti-inflammatory drugs are generally useful. These include hydroxychloroquine, chloroquine, ivermectin, tocilizumab, adalimumab, and ruxolitinib, all of which have been tried against the COVID-19 symptoms, with little curative effects [14]. Later studies questioned the efficacy [15] and none of them are found completely successful [16], which leaves the current COVID-19 treatment system as supportive care.

In the context of this state of uncertainty and lack of appropriate pharmacological interventions, this review article suggests looking into the plant kingdom to develop an appropriate drug to treat COVID-19 patients. It has been suggested after observing the beneficiary effects of several plant species in treating a number of significant diseases. For example, an alkaloid from the bark of the Cinchona tree (Cinchona officinalis; locally known as Quina Quina, meaning bark of bark or holy bark) named quinine was used with good effect to treat malaria [17]. The same quinine leads to the development of chloroquine and hydroxychloroquine, which were mentioned as modern antiviral and anti-inflammatory drugs. (The late Winston Churchill once said that 'Drinking gin and tonic (from the Cinchona tree) has saved more English men's lives and minds than all the doctors in the Empire', which highlights the significance of the Cinchona plant in mitigating and eradicating malaria.) In addition to Cinchona, the identification of the Colchicum plant (Autumn crocus) and its use in treating gout and Mediterranean fever [18] was a significant breakthrough in medical history. Other medicinal plant species have also been identified and assessed as having antimicrobial (including antiviral) or antiinflammatory properties or, indeed, having both at the same time [19-21]. In India, the major traditional treatment system known as 'Ayurveda' (meaning 'longevity') has been used in phytochemicals found in hundreds of identified plant species to treat several kinds of diseases for 5000-6000 years [22,23]. Similarly, traditional Chinese medicines use medicinal plants in their treatment protocols $[24,25]$. During the last two decades, several traditionally used medicinal plants have been subjected to study, and many alkaloids and flavonoids have been identified, which can treat several diseases [26].

In the absence of any suitable pharmaceutical intervention in western medicine to treat COVID-19 patients, the objective of this review is to highlight the potential of a medicinal plant species, commonly called licorice (Glycyrrhiza glabra), which belongs to the shrub category, whose phytochemicals have antiviral and anti-inflammatory properties, and to suggest that clinical trials be introduced to assess its potency regarding COVID-19 
symptoms. Phytochemicals from many other medicinal plants are also known to have similar properties, such as Sambucus nigarac [27], Desmodium canadense, Lamiaceae family, Asteraceae, Geraniaceae, etc. [28] but licorice has explicitly been suggested due to its: (i) considerable antiviral property against several viruses, including SARS-CoV, (ii) strong anti-inflammatory property, which has been observed in many rat model studies, (iii) autophagy-enhancing mechanism, (iv) established use in Chinese and Indian Ayurvedic medicines, and (v) wide distribution.

\section{Methodology}

Searches were conducted in the existing literature through Google Scholar, PubMed, Scopus, and Web of Science to obtain the most up-to-date research information regarding licorice's antiviral and anti-inflammatory properties. More broadly developed articles have not been included since this article's objective is to focus on licorice's antiviral and anti-inflammatory properties plus its autophagy-enhancing mechanism. To assist the discussion, this review contains a brief description of the mechanisms of inflammation in the human body and the actions of phytochemicals on it. Apart from general information about licorice, its antimicrobial, specifically antiviral, and anti-inflammatory properties, together with its autophagy-enhancing mechanism, are included. The review ends with a small discussion and conclusion.

\section{Phytochemical Actions on the Human Body}

Disease treatment with medicinal plants is common in many ancient cultures, including Indian, Egyptian, African, Chinese, Japanese, American Indian, and Australian Aboriginal [29-31]. This practice has a history of more than 5000 years, and it is still a significant source of health care for large numbers of people, particularly in the developing areas of the world [32]. The World Health Organization (WHO) has indicated its understanding of the significance of medicinal plants' treatment and has listed more than 21,000 medicinal plants [33]. Medicinal plants are used in the Ayurvedic treatment system for obesity, fatigue, multiple sclerosis, cardiovascular disease, asthma, depression, arthritis, cerebral injury, lung fibrosis, and many other diseases. Metabolic diseases, including infection and inflammation, are also treated in this fashion [34]. In addition to their use in the Indian subcontinent, herbal medicines are commonly used in China for medical treatment. Even though many respected cultures have used medicinal plants for thousands of years, only very recently have pharmacologists tried to identify and assess the healing potential of the phytochemicals inherent in these medicinal plants. In addition, herbal therapeutic effects on mitochondrial functions have been studied by many researchers [35-37].

When food is ingested, it can be either used for normal body functioning and growth, or in some circumstances, for healing purposes. Experience has shown that spices generally have an enhanced healing effect, but in the case of specific medicinal plants, the healing effect is much more significant. This has been summarized in a conceptual diagram showing the effect of food, spices, and plant-based medicines in Figure 1. Of particular interest here is that when a foreign material, for example, a modern drug, comes inside the body, the body can recognize it as foreign material and may reject it. The body may send it to the liver and come out through the urine, termed 'First pass effect.' In contrast, when a plant-based medicine is ingested, it is more likely to be accepted without stress because the body recognizes it as natural, like vegetables and fruits that we eat daily [37]. 


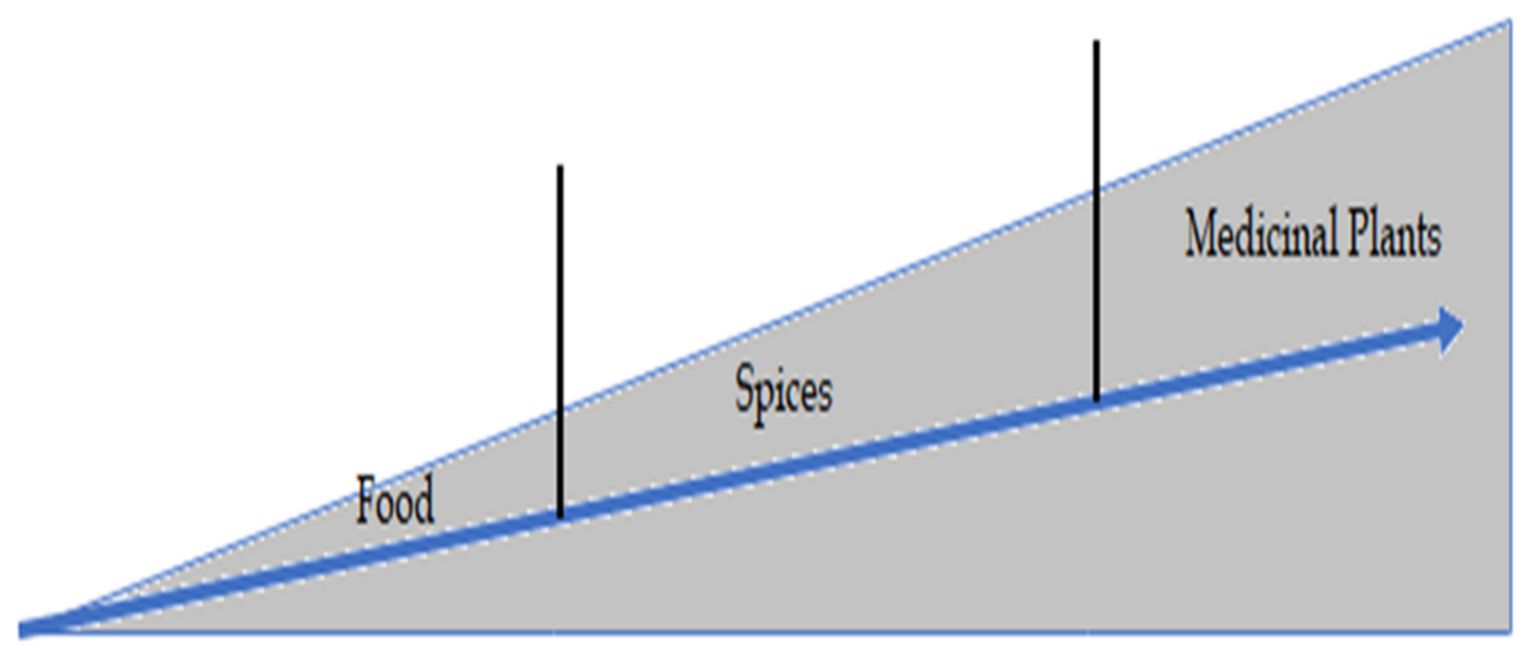

Figure 1. Conceptual diagram showing the comparative influence (on Y-axis) of food, spices, and medicinal plants (on $\mathrm{X}$-axis) on the human body [38].

It is relevant to note that plants do not have a comparable immune system to animals to act against microbial pathogens; instead, they work through a defense mechanism that induces various types of antimicrobial compounds such as proteins, peptides, and small molecular weight organic substances. These compounds are found to have significant therapeutic effects in animals and humans [20]. Consistent with this observation, through various recent studies, it has been found that many medicinal plants used for traditional treatments have their own phytochemicals suitable for extraction to provide therapeutic and healing effects [39,40]. These phytochemicals include alkaloids, flavonoids, terpenoids, and carotenoids, including nitrogen-containing compounds, with many having antimicrobial and anti-inflammatory properties [39-41].

In the literature, around 100 British Colombian medicinal plants have been identified, some with antiviral properties, including more than 10 with significant antiviral activity against the respiratory synclinal virus (RSV), herpes virus-1 (HSV-1), coronavirus (CoV), and parainfluenza virus-3 (PI3) [42]. Similarly, more than 800 Chinese medicinal plants were identified to have antiviral properties [43], including some useful against SARS-CoV [44]. It is also recognized that some of the plant extracts have shown efficacy against existing conventional drug-resistant viruses $[45,46]$. Several researchers studied the inhibitory effects of plant-based biomolecules on various pathogenic viruses such as Human immunodeficiency virus (HIV) [39,47], Hepatitis B virus [48], Herpes simplex virus-type 2 [49], and SARS-CoV [41,50] with successful results. Essential oils from several tree species have also shown antimicrobial, and specifically, antiviral properties. For example, it is reported that essential oils from Tea trees, Eucalyptus trees, Citrus spp., and Hyssopus officinalis could alter the fluidity of the viral membrane by insertion into the lipid double layer envelope, generating an inhibitory effect [21,51-55]. These known examples suggest that there may be many more potential antimicrobial compounds, specifically antiviral and anti-inflammatory agents, that need to be explored in the form of phytochemicals. Therefore, this review explores both the antiviral and anti-inflammatory actions and the autophagy-enhancing mechanism of licorice to suggest clinical trials for COVID-19 symptoms.

\section{Licorice (Glycyrrhiza glabra)}

Licorice (also called liquorice) is a Greek word meaning 'sweet root' and is a perennial herb native to southwestern Asia and the Mediterranean region in Europe [56] (Figure 2). The plant has been used in several locations in India, China, Greece, Europe, the Middle East, and Africa for various treatments, particularly those related to arthritis and ulcers [57]. It is known as 'Yashtimadhu' (sweet root) in Sanskrit and 'Gan cao' (sweet grass) in 
the Chinese language [57] and was also used in Arabic medicine in the Middle Ages and documented in the Canon of Ibn Sina (980-1037 AD) [56]. The herb belongs to the Glycyrrhiza glabra species in the Leguminosae family and grows to a height of around $2 \mathrm{~m}$ [58].

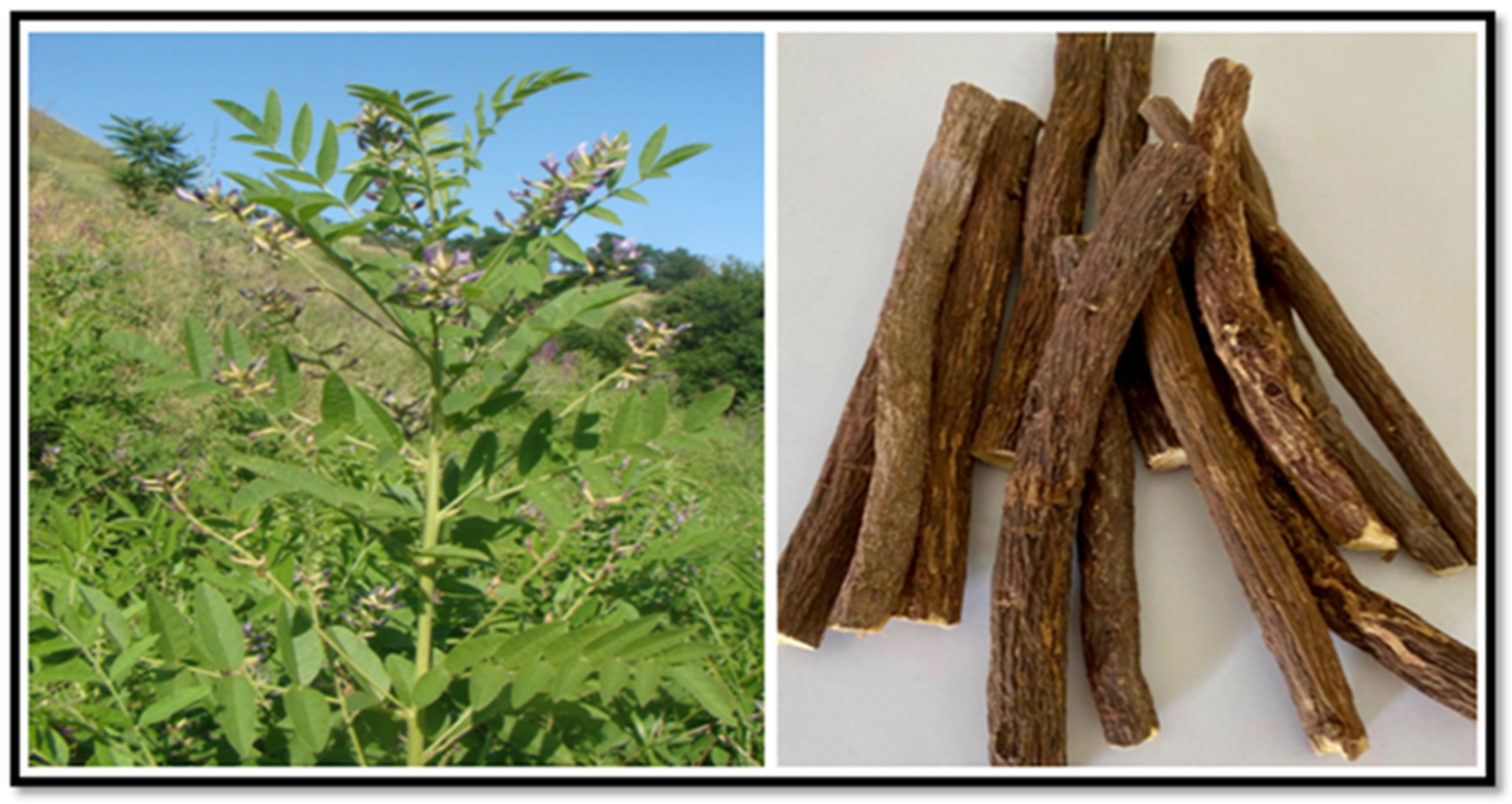

Figure 2. Licorice plant (left) and its root (right).

The plant has a long cylindrical-shaped, multi-branched root, which extends horizontally underground and is mainly used for medicinal purposes [59]. Licorice is 50 times sweeter than sugar due to the presence of glycyrrhizin (glycyrrhizic acid-GL) and is often used as a sugar substitute $[59,60]$. The plant has antioxidant properties; therefore, it is used in some cancer treatments $[59,61]$. The licorice family has three original plants used for treatment: G. uralensis, G. inflata, and G. glabra [62]. The licorice plant is considered a weed in many places like wheat crops and cotton plantations, together with potato, sugar beet, clover, and sainfoin fields, but it has been used as traditional medicine in many ancient civilizations such as for the Greeks, Romans, Egyptians, Assyrians, Indians, and Chinese [55,63].

Licorice falls into the list of first-line medicinal plants [64-66]. In ancient China and India, licorice has been used for more than 5000 years to treat respiratory and liver disease and alleviate the toxicity of other drugs $[56,62,63]$. The Ayurvedic Pharmacopoeia of India [63] mentions that licorice treats inflammation, eye and liver diseases, throat infections, peptic ulcers, and arthritis. Greeks used licorice to treat both gastric and peptic ulcers, whilst Europeans and Asians have utilized it to treat psoriasis [67]. It is a traditional Persian medicine to treat various diseases, including respiratory disease [68]. The role of licorice in Japan also needs to be highlighted as they have been using it to treat chronic hepatitis [68]. The plant also has anticancer, hepatoprotective, antispasmodic, neuroprotective, antioxidant, and estrogenic properties and is very useful in reducing hepatocellular damage in chronic hepatitis B and C patients [69]. For many years, it has had the reputation of being a memory booster [70] and an antidepressant [71] and can reduce blood cholesterol levels [72,73] and acts as a promising drug for treating liver and renal complications [74-76]. It is also found that the plant can reduce polydipsia and frequent urination in diabetic patients [69]. In some places, the root is used to prepare tea, and the dried root is used as a tooth cleanser [77].

When studies on the properties and therapeutic benefits of phytochemicals in the licorice have been undertaken, scientists discovered that they could extract more than 
20 triterpenes, 300 flavonoids, and 73 bioactive compounds from the root and identified 91 potential targets for its action [62,78,79]. Many of the extracted bioactive compounds were shown to have antimicrobial, antiviral, and anti-inflammatory properties, such as GL, $18 \alpha / \beta$-Glycerrhetinic acid (GA), three triterpenes, and several flavonoids (Table 1).

Table 1. A list of major bioactive compounds identified in licorice together with their therapeutical properties.

\begin{tabular}{|c|c|c|}
\hline Bioactive Compounds & Properties & References \\
\hline Glycerrhizin (GL) & Antimicrobial & \multirow[t]{2}{*}{ [80-82] } \\
\hline $18 \beta$-Glycerrhitinic acid & Antimicrobial, anti-inflammatory & \\
\hline$(\mathrm{GA})$ & Against Helicobacter pylori, & \multirow[t]{5}{*}[83-85]{} \\
\hline & MRSA, & \\
\hline & Clarithromycin-resistant $H$. pylori & \\
\hline $18 \alpha-\mathrm{GC}, 18 \beta-\mathrm{GC}$ & Anti-inflammatory & \\
\hline Flavonoids (13 Ns below) & Anti-inflammatory & \\
\hline & Antimicrobial, anti-inflammatory & \multirow{7}{*}{$\begin{array}{l}{[86]} \\
{[87]}\end{array}$} \\
\hline $\begin{array}{l}\text { Licochalcone } \mathrm{A} / \mathrm{B} / \mathrm{C} / \mathrm{D} / \mathrm{E}, \\
\text { isoliquiritigenin (ISL) }\end{array}$ & & \\
\hline $\begin{array}{c}\text { echinatin (EC), glabridin (GLD), } \\
\text { soangustone A (ISOA), }\end{array}$ & \multirow{5}{*}{ Antimicrobial } & \\
\hline licoricidin (LID), & & \\
\hline licorisoflavan A (LIA), & & \\
\hline dehydroglyasperin C (DGC), \& & & \\
\hline Glabridin & & \\
\hline Aqueous extract & B. Subtilis and E. Coli & [88] \\
\hline Methanol extract & Phytopathogenic fungi & [89] \\
\hline Glycyrhetinic acid & MRSA & [84] \\
\hline Licochalcone and Anti-fungal & & [90] \\
\hline Acetate root extract & K. pneumonia and A. baylyi & [91] \\
\hline \multicolumn{3}{|l|}{ Glabron } \\
\hline Licochalcone A/C/E & Staphylococcus aureus & [92] \\
\hline Glycyrrhizin & Helicobacter pylori & [93] \\
\hline $18 \beta$-Glycerrhetinic acid & Clarithromycin-resistant H. pylori & [85] \\
\hline
\end{tabular}

$\mathrm{GL}$ is a glycoside formed as a mixture of $\mathrm{Ca}, \mathrm{Na}$, and $\mathrm{K}$ salts of glycyrrhizinic acid.

The roots contain several phytochemicals such as $2 \beta-\mathrm{GL}$, glucuronic acid, GA, tannic acid asparagine, resins, volatile oils, flavonoids such as liquiritigenin (LG), liquiritin (LQ), isoliquiritigenin, isoliquiritin, and coumarin compounds such as herniarin and umbelliferone. They also contain glabridin compounds such as glycerin flavone, glabrene, glabryl, formononetin, and isoliquiritigenin [68]. Many of these compounds have several known benefits and have been used as neuroprotective, antidepressive, oestrogenic, sedative, antimicrobial, specifically antiviral, anticarcinogenic, immunoregulatory, hepatoprotective, and antioxidant properties [62,94].

\subsection{Antimicrobial Activity}

Many studies revealed the antibacterial activity of the plant (various extracts and flavonoids) against several bacteria strains, including Helicobacter pylori and methicillinresistant Staphylococcus aureus (MRSA) [58,84,92,95-97]. Mass and Cock [91] studied the antibacterial efficacy of Licorice and demonstrated that the acetate root extract exhibited strong antibacterial efficacy against K. pneumonia and A. baylyi, and Wu et al. [92] found that the flavonoids Glabrol, Licochalcone A, C, and E are very effective against Staphylococcus aureus. The activity of GA against MRSA was studied by Long et al. [84] and they found that the acid inhibits MRSA survival and attenuates virulent gene expression. Later, Celik and Duran [83] found that the same GA is very effective against Helicobacter pylori. Zhou et al. [98] believe that licochalcone could be used to synthesize novel anti-S. aureus compounds that may inhibit the production of $\alpha$-toxin in methicillin-sensitive $S$. 
aureus (MSSA) and MRSA. In addition to antibacterial efficacy, the antifungal efficacy of licochalcone and glabridin has been observed by Messier and Grenier [90].

\subsubsection{Antiviral Activity}

In Vitro Studies

One of the significant characteristics of licorice, which may be useful for treating COVID-19, is its antimicrobial property, particularly its antiviral effect $[95,99]$. The antiviral property of licorice is revealed by many researchers, with the first study being published in 1979 [100], whose finding was that GL and GA (structure in Figure 3) are the main compounds behind the antiviral efficacy [101]. Ashfaq et al. [102] investigated the antiviral characteristic of licorice against the hepatitis $C$ virus. They demonstrated that the plant extract could inhibit hepatitis $C$ virus' growth, including a 50\% reduction $(14 \pm 2 \mu \mathrm{g} / \mathrm{mL})$ in viral concentration (including assessment of the full-length particle and core gene expression). Through the experiment, Matsumoto et al. [101] found that GL targets the release step of the hepatitis C viral infection, which identified a potential role for GL in hepatitis C treatment. Huang et al. [103] studied the effect of GL on HIV infection and found that GL perfusion can inhibit HIV infection by reducing its adhesion and stress components. Later, the efficacy of GL against Coxsackievirus A16 (CVA16) and Enterovirus 71 (EV71) was studied by Wang et al. [57]. GL's effectiveness against the influenza virus was also studied, and it was observed that GL could inhibit the H5N1-induced production of chemokine ligand 5 (C-C motif CCL5) and ligand 10 (C-X-C motif, CXCL10), together with IL-6 [104-106]. It was also found that GL can suppress H5N1-induced apoptosis activity at a concentration of $100 \mu \mathrm{g} / \mathrm{mL}$ [104]. Apart from this, the action of GL against the herpes simplex virus (HSV1) is studied by Laconi et al. [107] and found that pre-treatment with GL on the HeLa cell improved the antiviral property (when experimented with HSV1) by a factor of 95 to $98 \%$. Besides viral inhibition, GL also evidences immunostimulant activity against viruses such as the duck hepatitis virus (DHV) [108]. Both antiviral and antitumor activity of licorice root extracts were investigated by Fukuchi et al. [109], who found that the alkaline extracts demonstrated higher antiviral activity against HIV compared to the water extract. This led the authors to suggest that this extract may be converted into mass production as an anti-HIV agent.
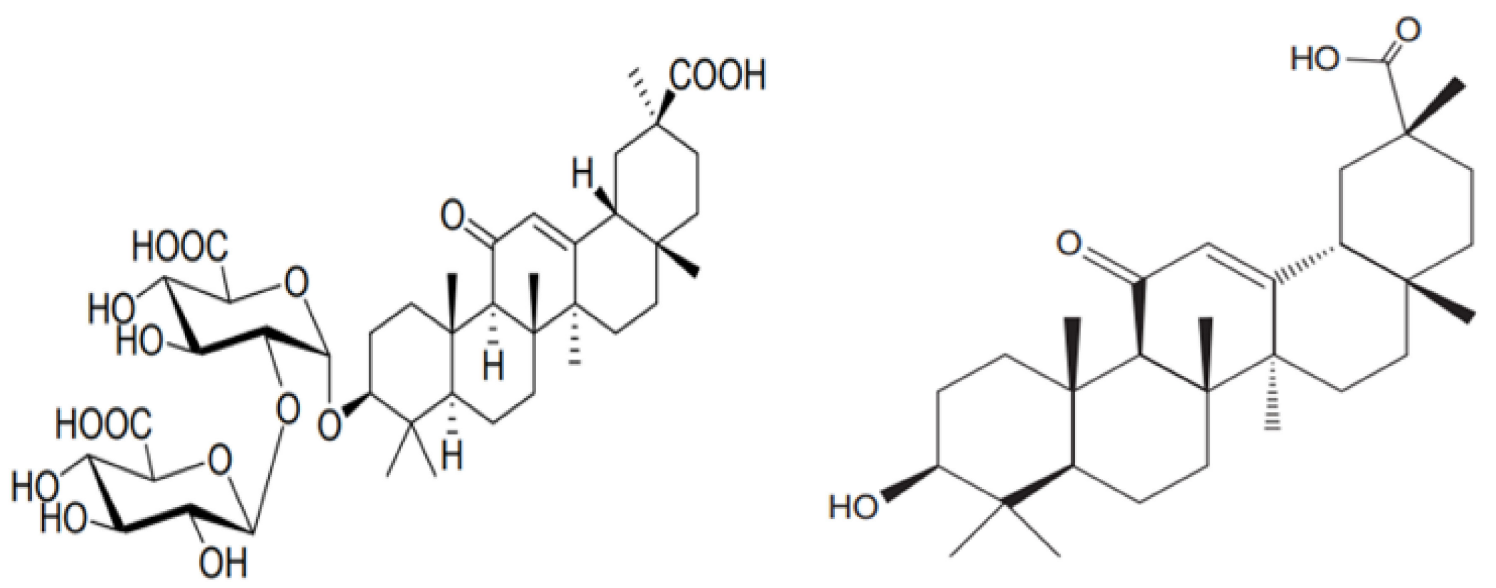

Figure 3. Chemical structure of Glycyrrhizic Acid (GL) (left) and 18ß-Glycerrhitinic acid (GA) (right).

An epidemic with a severe coronavirus (SARS-CoV) started in 2002 in China and spread to 32 countries. After this epidemic, many researchers studied the efficacy of licorice, specifically GL, on SARS-CoV. The study of Hoever et al. [110] is significant, and their in vitro study revealed that GL was able to inhibit virus replication. Among the $15 \mathrm{GL}$ derivatives, 2 -acetamido- $\beta$-D glucopyranosylamine, when inserted into the glycoside chain of GL, showed a ten-fold higher antiviral efficacy than normal GL. It was also observed that GL could inhibit the absorption and penetration of the SARS-CoV in the early replicative 
cycle, specifically when given during and after the absorption period. However, due to the complexity of this mechanism, the exact activity details are unclear, but there is a suggestion that nitrous oxide (NO) donation is somehow involved [56,111].

Apart from GL, the antiviral activity of GA was also studied against many viruses, including the human respiratory syncytial virus (HRSV), arbovirus, vaccinia, and vesicular stomatitis. It was identified that both GL and GA could induce interferons that can bind to cell surfaces and stimulate the synthesis of intracellular proteins, blocking the transcription of viral DNA [112]. Interferon also activates the macrophages and stimulates the augmentation of the natural killer cell activity [112]. All of these studies demonstrate that GL and GA in licorice, particularly GL, can be used as a potential antiviral drug (Table 2). Therefore, it is suggested to undertake in vitro and in vivo studies followed by clinical trials to investigate the antiviral efficiency of GL against SARS-CoV-2 replication.

Table 2. A list of significant phytochemicals present in licorice and their antiviral efficacy.

\begin{tabular}{ccc}
\hline Compounds in Licorice & Antiviral Property against & Reference \\
\hline Glycyrrhizic acid & SARS-CoV & {$[111]$} \\
Glycyrrhizic acid derivatives & SARS-CoV & {$[110]$} \\
Glycyrrhizic acid & Hepatitis A (HAV) & {$[113]$} \\
Glycyrrhizic acid & Hepatitis B (HBV) & {$[81,114,115]$} \\
Glycyrrhizic acid & Hepatitic C virus & {$[101,102,116,117]$} \\
Glycyrrhizic acid & Human immune deficiency & {$[103,118-120]$} \\
Alkali root extract & (HIV) Virus & {$[109]$} \\
Glycyrrhizic acid & HIV & {$[121]$} \\
& Herpes viridae (varicella) & {$[122]$} \\
& Zoster virus (VZV) & {$[122]$} \\
& Epstien-Barr virus (EBV) & {$[123]$} \\
& Cytomegalovirus (CMV) & {$[124]$} \\
Glycyrrhizic acid & Coxasackievirus B3 (CVB3) & {$[57]$} \\
& Coxasackievirus A16 (CVA16) & {$[104-106]$} \\
& H5N1 influenza virus & {$[108]$} \\
Water extract & Duck Hepatitis virus & {$[107]$} \\
$18 \beta$-glycyrrhetinic acid & Herpes simplex virus-1 & {$[125]$} \\
\hline
\end{tabular}

\section{In Vivo Studies}

The effect of GL on the influenza virus was conducted in a mouse model study more than two decades ago. The mice were treated with $10 \mathrm{mg}$ of GL/ $\mathrm{kg}$ body weight intraperitoneally (IP) one day before exposure to the virus (lethal dose able to kill around $50 \%$ of the animals). The result was successful, with all the GL-treated animals surviving the experimental period of 21 days, whereas, for the control animals, the mean survival time was only 10.5 days [127]. The efficacy study of GL in murine herpes encephalitis revealed that the IP administration of GL increased the survival rate of animals by 2.5 times, and the viral replication in the brain was found to reduce more than $45 \%$ [128]. A study with Coxsackievirus B3 (CVB3) revealed that GL is a factor in improving the state of Coxsackievirus B3 (CVB3)-induced myocarditis [124].

\section{Human Studies}

During the SARS-CoV epidemic in China (2002-2003), Lu et al. [129] conducted a clinical trial with GL against SARS-CoV on the virus confirmed patients. Among the 73 patients, 37 were treated with GL. After the complete treatment regimen, the major symptoms vanished quickly in the treated group compared to the placebo. Another trial was conducted on 60 SARS-CoV patients, with half belonging to the interventional group. The average period from peak severity of the lesions to $50 \%$ improvement was shorter in the interventional group treated with GL [130]. 


\subsection{Anti-Inflammatory Property}

Inflammation plays a significant role in epidemic and pandemic diseases, and licorice is considered an alternative choice for the treatment $[62,131]$. Inflammation is primarily a protective measure against microbial invasion, which includes action against the presence of toxins or allergens. However, in some cases, such as COVID-19, it may become uncontrollable and detrimental to the tissues and organs $[132,133]$. It is the primary cause of many human diseases such as asthma, rheumatoid arthritis, and atherosclerosis [134]. The inflammatory response occurs as a result of the production of pro-inflammatory cytokines such as IL-1, IL-6, IL-12, IL-18, interferon (INF)- $\gamma$, tumor necrosis factor (TNF), and granulocytemacrophage colony-stimulating factor $[134,135]$. The activity of the nuclear factor-kB (NF-kB) and transcription factors also play a significant role in inflammation by regulating the expression of various genes that encode the pro-inflammatory cytokines, adhesion molecules, chemokines, growth factors, and inducible enzymes such as cyclooxygenase- 2 (COX-2) [135].

Since ancient times, licorice has alleviated pain, relieving coughing, eliminated phlegm, and treated respiratory, liver, and gastric diseases [136]. Like its antimicrobial activity, the anti-inflammatory activity (microbial induced inflammation) of licorice and its mechanism has been studied by many researchers [59,62,137-139]. It has been found that the action is similar to those of glucocorticoids and mineralocorticoids and is mainly due to the presence of GL [139-141] and GA in Licorice [59,141]. Glabridin, liquiritin, liquiritigenin, and licochalcone, including 13 flavonoids, are present in licorice, in addition to GL and GA, and all these compounds have shown significant anti-inflammatory activity $[62,86,142]$. Therefore, these compounds are used against liver and renal complications [143]. The following are some of the studies that highlight GL and GA's influence in treating various inflammatory diseases.

\subsubsection{In Vitro Studies}

There are several in vitro studies conducted to investigate the anti-inflammatory property of licorice, specifically the effects of GL and GA. Wang et al. [144] investigated the same effects in lipopolysaccharide (LPS) stimulated macrophage model on RAW264.7 cells by treating with $25-75 \mu \mathrm{M}$ GA or $18 \beta \mathrm{GA}$ and found that both are potential agents for the treatment of inflammatory-mediated diseases. They realized that both compounds inhibited the NF-kB activation and the activities of phosphoinositide-3-kinase (P13K) and reduced the production of LPS-induced tumor necrosis factor- $\alpha$ (TNF- $\alpha$ ), IL- 6 , and IL-1 $\beta$ in a dose-dependent manner [144]. Similarly, Bai et al. [145] explored the anti-inflammatory effect of licorice residues and reported that a compound in the residue (compound 18) displayed the highest anti-inflammatory effect (No inhibitory effect) in the RAW264.7 cells. Further studies revealed that the anti-inflammatory effect happened through the downregulation of the pro-inflammatory cytokines (IL-1 $\beta$, IL-6, inducible nitric oxide synthase (iNOS), and cyclooxygenase-2 (COX-2)) [145]. Apart from GL and GA, one licorice extract named licoflavanone also showed strong anti-inflammatory activity in LPS-stimulated RAW 264.7 murine macrophages [146].

\subsubsection{Animal Studies}

Aly et al. [59] studied the anti-inflammatory activity of licorice using the carrageenaninduced edema model in male albino rats at the Al-Isra University in Jordan. They found that aqueous licorice extract and GA in licorice demonstrated significant antiinflammatory activity similar to diclofenac sodium (DS). Similarly, in a mouse model study, Xiao et al. [147] investigated the influence of GA in Propionibacterium acnes-induced acute inflammatory liver injury. They found that GA exhibits anti-inflammatory effects through the inhibition of pro-inflammatory cytokines (such as IFN- $\gamma$ and TNF- $\alpha$ ), P. acnesinduced NF-kB activation, and chemokine expression (MIP-1 $\alpha$ ). Another investigation on the anti-inflammatory effects of GL found that it significantly inhibited the LPS-induced inflammatory response in a mouse by inhibiting the TLr4 signaling pathway [148]. 
The anti-inflammatory activity of GA and hydroxypropyl $\gamma$ cyclodextrine was investigated against small intestine injury on indomethacin-treated mice. A significantly high plasma concentration of GA was detected after the oral administration of the compound [149]. It was also found that $18 \beta$-glycyrrhetinic acid-hydroxypropyl- $\gamma$ cyclodextrin compound reduced the mRNA expression of the IL- 6, IL- $1 \beta$, including TNF- $\alpha$ and thus showed a potential therapeutic value against indomethacin-induced small intestine injury [149]. The ethanol extract of roasted licorice was also reduced in the TNF- $\alpha$ and IL-6 and increased IL-10 in LPS treated mice, which facilitated the survival rate [150]. Apart from this, many other studies also showed the anti-inflammatory property of licorice on live animals [151], and the details are summarized in Table 3.

It was reported that IP administration of GL suppressed the lung inflammation caused by the infection of Streptococcus aureus in a mouse model study [152]. Further to this, it has been mentioned that GL has a protective effect against TLR4 activator LPS-induced acute respiratory distress syndrome (ARDS) in mice [153]. Similarly, in a mouse model experiment, it is observed that GL reduced the mortality of influenza-infected mice by interferon $\gamma$ and T cell activation [127]. Menegazzi et al. [154] injected carrageenan (a well-known acute model inflammation widely used for inflammatory research) into the pleural cavity of mice to investigate GL's influence in reducing inflammation, and they observed that the injection resulted in inflammation with fluid accumulation in the pleural cavity, mainly as a result of the production and accumulation of TNF- $\alpha$ and IL-1 $\beta$. The researchers noted that these inflammation events occurred as a result of the activation of NF-kB, including the activation of signal transducer and activator transcription-3 (STAT-3) in the lung [154]. However, surprisingly GL inhibits these activation results in the reduction of inflammatory response.

Table 3. The anti-inflammatory property of licorice extracts in various studies.

\begin{tabular}{|c|c|c|c|c|c|}
\hline Compound & Tissue/Disease & Concentration & Method & Inhibition Rate & Reference(s) \\
\hline \multicolumn{6}{|c|}{ In vitro studies } \\
\hline $8 \beta-G L$ & $\begin{array}{l}\text { LPS }\left(1 \mu \mathrm{g} \mathrm{mL} L^{-1}\right) \text {-induced } 1 \\
\text { Murine cell (RAW 264.7) }\end{array}$ & $75 \mu \mathrm{M}$ & ELISA & $\begin{array}{c}\text { 51\%-NO, 51\%-IL-1 } \beta, \\
49 \%-P G E 2 \& \text { 42\%-IL-6 }\end{array}$ & [144] \\
\hline $18 \beta-G L$ & $\begin{array}{c}\text { LPS }\left(1 \mu g \mathrm{~mL}^{-1}\right) \text {-induced } \\
\text { murine Cell (RAW } 264.7 \\
\text { macrophages) }\end{array}$ & 0.5 or $1 \mathrm{mg} \mathrm{mL}^{-1}$ & ELISA & $\begin{array}{c}\text { Supress PGE2, } \\
\text { PGI2,TXB2 \& LTB4 }\end{array}$ & [155] \\
\hline $18 \beta-\mathrm{GL}$ & $\begin{array}{l}\text { Leishmania donovani infected } \\
\text { Macrophages-BALB/c mice } \\
\text { (age: } 4-6 \text { weeks) }\end{array}$ & $50 \mathrm{mg} \mathrm{mL}^{-1}$ & ELISA & 90.94\%-parasite load & [156] \\
\hline $18 \beta-G A$ & $\begin{array}{l}\text { LPS }\left(1 \mu \mathrm{g} \mathrm{mL} \mathrm{m}^{-1}\right) \text {-induced } \\
\text { murine cell (RAW } 264.7 \text { cell) }\end{array}$ & $75 \mu \mathrm{M}$ & ELISA & $34 \%-\mathrm{NO}$ & [144] \\
\hline $18 \beta-\mathrm{GA}$ & & $75 \mu \mathrm{M}$ & ELISA & $\begin{array}{l}58 \%-P E G 2,42 \%-1 L-1 \beta \\
35 \%-I L-6,34 \%-T N F-\propto\end{array}$ & [144] \\
\hline LID & $\begin{array}{c}\text { LPS }\left(0.1 \mu \mathrm{g} \mathrm{mL} \mathrm{m}^{-1}\right) \text {-induced } \\
\text { U937 Cell line (human } \\
\text { monoblastic leukaemia cell line) }\end{array}$ & $0.1,0.5,1 \mu \mathrm{g} \mathrm{mL}-1$ & & $\begin{array}{l}\text { Decreased the secretion } \\
\text { of IL-6, MMP-7, MMP-8, } \\
\text { \& MMP-9 }\end{array}$ & {$[157]$} \\
\hline DGC & $\begin{array}{l}\text { Glutamte }(5 \mathrm{nM}) \text {-induced } \\
\text { HT22 cells }\end{array}$ & $2 \mu \mathrm{M}$ & 2,7-DCF assay & $\begin{array}{l}\text { Dose-dependent } \\
\text { inhibition of ROS assay \& } \\
\text { WB production }\end{array}$ & [158] \\
\hline LIA & $\begin{array}{c}\text { LPS }\left(0.1 \mu \mathrm{g} \mathrm{mL} \mathrm{m}^{-1}\right) \text {-induced } \\
\text { U937 cell line (human } \\
\text { monoblastic leukaemia cell line) }\end{array}$ & $0.1,0.5,1 \mu \mathrm{g} \mathrm{mL}-1$ & & $\begin{array}{c}\text { Decreased the secretions } \\
\text { of CCL5 @ }\left(1 \mu \mathrm{g} \mathrm{mL}^{-1}\right) \\
\text { MMP-7 } @(0.5, \\
1 \mu \mathrm{g} \mathrm{mL}-1) \mathrm{MMP}^{-8} @ \\
\left(0.5,0.1,1 \mu \mathrm{g} \mathrm{mL}^{-1}\right)\end{array}$ & [157] \\
\hline LCA & $\begin{array}{c}\text { LPS }\left(\mu \mathrm{g} \mathrm{mL}^{-1}\right) \text { induced murine } \\
\text { cells (RAW 264.7) }\end{array}$ & $3 \& 10 \mu \mathrm{M}$ & DCFH-DA & $\begin{array}{c}>80 \% \text { PGE2 inhibition @ } \\
10 \mu \mathrm{M} \text { fluorometric }>50 \% \\
\text { NO inhibition at }\end{array}$ & [151] \\
\hline
\end{tabular}


Table 3. Cont.

\begin{tabular}{|c|c|c|c|c|c|}
\hline Compound & Tissue/Disease & Concentration & Method & Inhibition Rate & Reference(s) \\
\hline $18 \beta-G L$ & LPS $\left(\mu \mathrm{g} \mathrm{mL}^{-1}\right)$ induced & $75 \mu \mathrm{m}$ & ELISA & $51 \%$ reduction in NO & [144] \\
\hline & $\begin{array}{l}\text { Murine cells (RAW } \\
264.7 \text { cells) }\end{array}$ & & & $\begin{array}{l}51 \% \text { reduction in IL- } 1 \beta \\
49 \% \text { reduction in PGE2 } \\
46 \% \text { reduction in } \\
\text { TNF- } \alpha \\
42 \% \text { reduction in IL- } 6\end{array}$ & \\
\hline $18 \beta-G A$ & & $75 \mu \mathrm{m}$ & ELISA & $58 \%$ reduction in PEG2 & [159] \\
\hline $\begin{array}{l}\text { Glabridin \& } \\
\text { isoliquiritigenin }\end{array}$ & & $20-40 \mu \mathrm{g} \mathrm{mL}^{-1}$ & $\begin{array}{l}\text { Cell culture \& } \\
\text { cell viability } \\
\text { assay }\end{array}$ & $\begin{array}{l}\text { anti-inflammatory } \\
\text { activity is due to the } \\
\text { individual or } \\
\text { synergistic effects }\end{array}$ & \\
\hline \multicolumn{6}{|c|}{ In vivo studies } \\
\hline Compounds & Inflammation Details & Models & Treatment & Result(s) & Reference \\
\hline $18 \alpha-\mathrm{GL}$ & $\begin{array}{l}20 \% \text { paraquat poisoning } \\
\text { solution @ } 15 \mathrm{mg} \mathrm{kg}^{-1}\end{array}$ & $\begin{array}{l}\text { Sprague Dawley } \\
\text { rats-male } 30 \mathrm{Ns} \\
\quad(180-200 \mathrm{~g})\end{array}$ & $\begin{array}{l}\text { injection-IP } \\
30 \mathrm{mg} \mathrm{kg}^{-1}\end{array}$ & $\begin{array}{l}\text { Significant decrease in } \\
\text { intercellular adhesion } \\
\text { molecules (ICAM-1) } \\
\text { and matrix } \\
\text { metalloproteinase-9 } \\
\text { (MMP-9) }\end{array}$ & [147] \\
\hline $18 \beta-G L$ & $\begin{array}{c}\text { LPS } \\
\left(1 \mathrm{mg} \mathrm{kg}^{-1}\right) \text {-Intratracheal } \\
\text { installation }\end{array}$ & $\begin{array}{l}\text { BALB/C mice } \\
\text { (male 20-25 gm) }\end{array}$ & $\begin{array}{l}\text { injection-IP 10, } \\
25 \& 50 \mathrm{mg} \mathrm{kg}^{-1}\end{array}$ & $\begin{array}{l}\text { Noted decrease in NO } \\
\text { and MPO activity }\end{array}$ & [160] \\
\hline LCA & $\begin{array}{l}\text { Topical inflammation } \\
\text { induced instantly at the } \\
\text { posterior surface of the ear } \\
\text { (using xylene } 0.05 \mathrm{~mL} \text { ) }\end{array}$ & $\begin{array}{l}\text { Kunming mice } \\
(20-25 \text { gm }) \& \\
\text { Wistar rats } \\
(150-200 \text { gm })\end{array}$ & $50 \mathrm{mg} \mathrm{kg}^{-1}$ & $\begin{array}{c}\text { Decrease in ear } \\
\text { oedema rate by } 30.3 \%\end{array}$ & [161] \\
\hline \multicolumn{6}{|c|}{ Human Studies } \\
\hline GL & $\begin{array}{l}\text { Hepatitis B virus induced } \\
\text { inflammation }\end{array}$ & Humans & $\begin{array}{c}\text { oral and IV } \\
\text { (60 mL daily) for } \\
\text { a week) }\end{array}$ & $\begin{array}{c}\text { Effective in } \\
\text { normalizing serum } \\
\text { (for } 7 \text { days, later } 3 \\
\text { days transaminases) }\end{array}$ & [115] \\
\hline GL & $\begin{array}{l}\text { Hepatitis } C \text { virus induced } \\
\text { inflammation }\end{array}$ & Humans & $\begin{array}{c}40 \mathrm{~mL} \\
\text { transaminases }\end{array}$ & $\begin{array}{l}\text { Found effective in } \\
\text { normalizing serum }\end{array}$ & [116] \\
\hline GL & $\begin{array}{l}\text { Hepatitis virus induced } \\
\text { Inflammation }\end{array}$ & Humans & 40 mg of GL (IV) & Suppressed ALT & [80] \\
\hline
\end{tabular}

NB: GL-Glycyrrhizin; GA—glycyrrhetinic acid; LID—licoricidin; DGC—dehydroglyasperin; LIA—licorisoflavan A; LCA—licochalcone A; LCB-licochalcone B; LCC_licochalcone C, LCD_licochalcone D; LCD_licochalcone D; LCE-licochalcone E; ALT_alanine aminotransferase; IP-Intraperitoneal.

\subsubsection{Human Studies}

The influence of licorice extracts, GL and GA, on humans was studied by many researchers, who found that both effectively inhibit the viral replication and inflammatory response [81,114,162]. Miyake et al. [80] conducted a study that administered $40 \mathrm{mg}$ of GL by injection to patients with chronic viral hepatitis and evaluated dose-response levels, including the frequency of administration. They found that GL effectively suppressed the alanine aminotransferase (ALT) in patients [80]. Zhang and Wang [82] also mentioned the efficacy of GC in lowering the ALT levels in chronic hepatitis B patients. In the LPS model of inflammation, GL can reduce TLR4 expression in the lung and the heart by significantly reducing the cytokine release $[153,163]$. 


\subsubsection{Mechanism}

The mechanism behind the anti-inflammatory activity of GL and GA is very complex. Antimicrobial activity is considered one of the best anti-inflammatory methods as microbial inhibition reduces inflammation [141]. It is reported that GL makes the anti-inflammatory activity by influencing the adrenal gland and thereby stimulating the body's own antiinflammatory adrenal steroid hormone, named cortisol, whenever required. It can also break down the post-action of the excess cortisol $[137,164]$. Studies reported that GL and GA could activate cortisone activity by (i) binding with glucocorticoid receptor (GR) signaling need for production [165], (ii) inhibiting the activity of corticosteroid 11 $\beta$-dehydrogenase isozyme $2(11 \beta-H S D 2)$, which usually converts active cortisol into inactive cortisone [166], and (iii) eliminating the oxidative stress within the body [167].

The high-mobility group box 1 protein (HMGB1) is a nuclear component but acts as a signaling molecule in acute and chronic inflammation [168]. Anti-inflammatory action is characterized mainly by the promotion of immunity, inhibiting the pathogen and pathogeninduced macrophage responses, specifically by binding with high-mobility group box-1 (HMGB1) and modulating P13K signaling [142,167-170]. According to Yu et al. [142], inducible nitric oxide synthase (iNOS) and cyclooxygenase-2 (COX-2) are responsible for the over-production of cytokines and inflammation. Therefore, inhibition of iNOS and COX2 is considered the most efficient approach in inhibiting the inflammatory response and the subsequent disorders. After a detailed study, Yu et al. [142] demonstrated that active licorice extract components GA, LQ, and LG could strongly (i) inhibit the production of NO in mice microglial cells (LPS activated), (ii) suppress the expression of IL-6, IL-1 $\beta$, TNF- $\alpha$ in LPS treated cells, and (iii) attenuate the COX-2 and iNOS expressions in LPS stimulated BV2 cells (Figure 4). Bodet et al. [169] also investigated the anti-inflammatory efficacy of licorice on periodontal disease using a super-critical carbon dioxide extract. They found that the extract exhibits anti-inflammatory activity by inhibiting the periodontal-pathogen-induced macrophage responses (IL-6, IL-8, IL- $1 \beta$, and TNF- $\alpha$ ) and phosphorylation of macrophage intracellular signaling proteins. The licorice extract also inhibited the pro-inflammatory cytokine response in the ex vivo human whole blood model [169]. Studies in rheumatoid arthritis and periodontitis patients revealed that TNF- $\alpha$ is an autocrine stimulator and a potent paracrine inducer of pro-inflammatory mediators, including interleukins (IL-1, IL-6, and IL-8) and is a granulocyte-macrophage colony-stimulating factor [171,172]. When a licorice extract was applied to a HaCaT human keratinocyte cell line, it attenuated the tumor necrosis factor- $\alpha$ (TNF- $\alpha$ ) and chemokine production by the interferon- $\gamma$ mediated pathway by targeting the STAT-1 and NF-kB signaling (in keratinocyte) pathways [173]. It also has been shown to control the production of PGE2 by the synovial cells that cause tissue destruction [174].

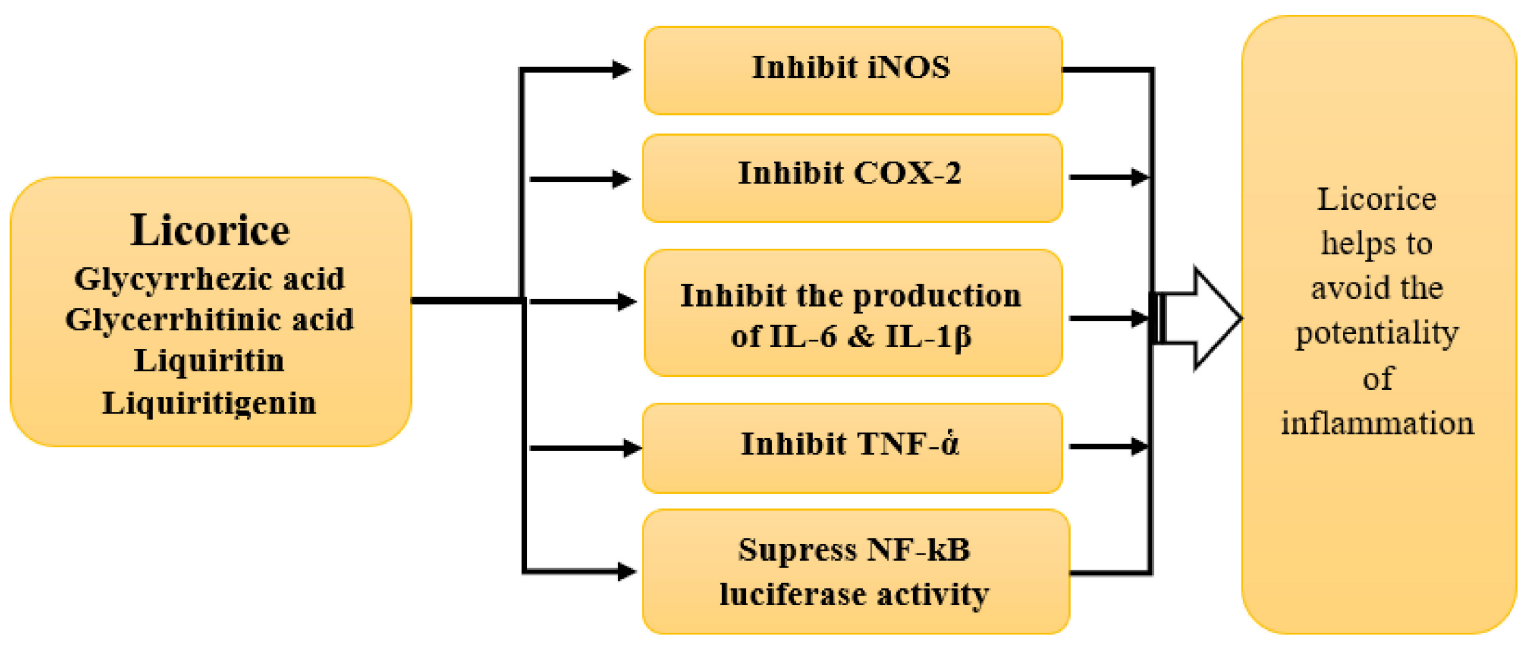

Figure 4. Schematic diagram showing the action of licorice in inhibiting the inflammation. 
Because of its anti-inflammatory property, both GL and GA can protect rat hepatocytes from bile acid-induced cytotoxicity [175]. The beneficial effect of GL on hepatitis patients was observed when intravenously administered, resulting in decreased serum ALT, necro-inflammation, and liver fibrosis [176]. Due to its strong anti-inflammatory activity, Li et al. [177] and Ye et al. [178] suggested that licorice could be used to treat renal and liver problems. The study of Zhang et al. [179] is also significant when considering the case of COVID-19, as their research demonstrated the inhibition of pro-inflammatory cytokines (nuclear factor-kB, interleukin-1 $\beta$, interleukin-6) in CVB-3-induced myocarditis patients. In addition to the above studies, randomized controlled trials revealed that GL and its derivatives could reduce hepatocellular damage caused during chronic hepatitis B and C [180]. Most of the studies used licorice extract, but a 2010 study highlighted that roasted licorice has more potent anti-inflammatory activity compared to raw licorice [181].

In the pulmonary system, NF-kB activation is considered a focal pathway in generating inflammation, and several noxious stimuli are responsible for this activation [182]. However, through rodent model studies, it has been observed that pre-treatment with nonspecific inhibitors can reduce inflammation [183]. The angiotensin-converting enzyme -2 (ACE-2) is the main pathway in which the SARS-CoV-2 enters the host cell. Therefore, any actions that reduce the number of ACE-2 are considered as safe. However, from the inflammation point of view, it has been observed that ACE-2 suppresses the toll-like receptor 4 (TLR4) and hence the inflammation in the lung. Therefore, the reduction in ACE-2 expression is controversial in nature. In addition to GL and GA, licochalcone has also shown significant anti-inflammatory activity (in vitro and in vivo) by suppressing the NF-kB activation and p38/ERK MAPK signaling [184]. These studies (Table 3) confirmed the high potential for GL and GA to act as a novel therapeutic intervention to alleviate inflammation, specifically in COVID-19 patients.

\subsection{Effect on Autophagy}

Autophagy is a cellular mechanism that cells use to adapt to stress conditions, including the internal invasion of pathogens. The process helps to clear out the pathogens, thereby reducing pathogen replication and the subsequent inflammatory consequences. However, some viruses like SARS-CoV-2 and HSV-1 can inhibit autophagy mechanisms to suit their replication conditions. This mechanism is usually linked to the inhibition of Beclin-1, which is considered one of the first proteins that a cell produces in the autophagic process $[185,186]$. In addition to its antiviral and anti-inflammatory properties, it is found that the GL can induce the autophagy mechanism in the cells by increasing the concentration of Beclin-1 [107]. After $24 \mathrm{~h}$ of treatment with GL, it was observed that the Beclin-1 production significantly increased $(p<0.01)$ (by two-fold to three-fold) in comparison with rapamycin treatment (Figure 1 in [107]). This is an important requirement in SARS-CoV-2 infected cells, as the SARS-CoV-2 virus inhibits Beclin- 1 levels by inducing the production of SKP2 proteins $[187,188]$. When GL was added to the cell $24 \mathrm{~h}$ before adding the herpes simplex virus (HSV1), Becklin production increased, and the cell demonstrated higher antiviral effects. The pre-treatment $(2 \mathrm{mM})$ increased the Beclin-1 production around five-fold compared to that induced at time zero. When GL was added to the HeLa cell together with HSV1, a strong antiviral activity was exhibited, whereas by comparison, the more traditional rapamycin treatment did not show any activity [107]. This finding highlights GL's ability to act as a prophylactic against HSV1, and it is suggested that it may also work against other viruses, including SARS-CoV-2.

\section{Discussion}

Based on various studies conducted across the world, it is clear that licorice has potent antimicrobial, anti-inflammatory, anticancer, and antioxidant properties [74,189,190]. Studies revealed that GL is hydrolyzed to enoxolone (GA) by intestinal bacteria in the gut. After absorption from the gut, the same GA is metabolized into $3 \beta$-monoglucuronyl- $18 \beta$ glycyrrhetinic acid in the liver [74]. The resulting metabolite is able to circulate in the liver, 
and hence the oral bioavailability is poor compared to intravenous administration [191]. To support this, through a rat model study, Egashira et al. [192] also reported that the IV and IP (intraperitoneal) administration of GL could provide more bioavailability than oral bioavailability. Among the 20 triterpenoids and more than 300 flavonoids present in licorice, two particular triterpenes, GL and GA, are thought to be mainly providing antimicrobial activity. In addition to GL and GA, the flavonoid named chalcone has a significant role in inhibiting bacterial infections. Analysis of the licorice plant has indicated that its underground portion is the most bioactive part [193]. Multiple studies have established that GL and GA organize viral inhibition through three specific activities: (i) inhibiting the gene expression and replication of the virus, (ii) minimizing adhesion force and facilitating stress reduction, and (iii) reducing the DNA binding ability of HMGB1 [141,142,146,173]. In contrast, licochalcones inhibit bacterial infection by (i) bacterial gene reduction, (ii) bacterial growth inhibition, and (iii) reduction of toxin production [92,194]. A dose-dependent therapeutic response was also observed in hepatitis patients [80], which is understood to suppress the alanine aminotransferase (ALT) levels in patients with chronic symptoms. It has also been found that GL can prevent tissue injury caused by chronic hepatitis and many other diseases [180]. Of particular interest to this discussion is that the significance of GA in treating inflammation was observed by Shi et al. [195] in a mouse model study. They found that treatment with GA inhibited hepatic inflammatory activity by blocking the high mobility group box-1 (HMGB-1) cytokine activity, suggesting a new therapy for acute viral hepatitis. In addition to this finding, a second mouse model study highlighted the significance of GL in protecting mice exposed to the influenza virus [127].

It is well established that, amongst other actions, SARS-CoV-2 infection becomes serious because of lung inflammation and multi-organ failure [196]. It is currently hypothesized that many lives could be saved if we could reduce the inflammation among seriously ill COVID-19 patients. The three key properties of licorice, its antiviral action, the autophagy enhancing mechanism, and its anti-inflammatory ability, might be able to improve the health status of COVID-19 patients in the following ways (Figure 5):

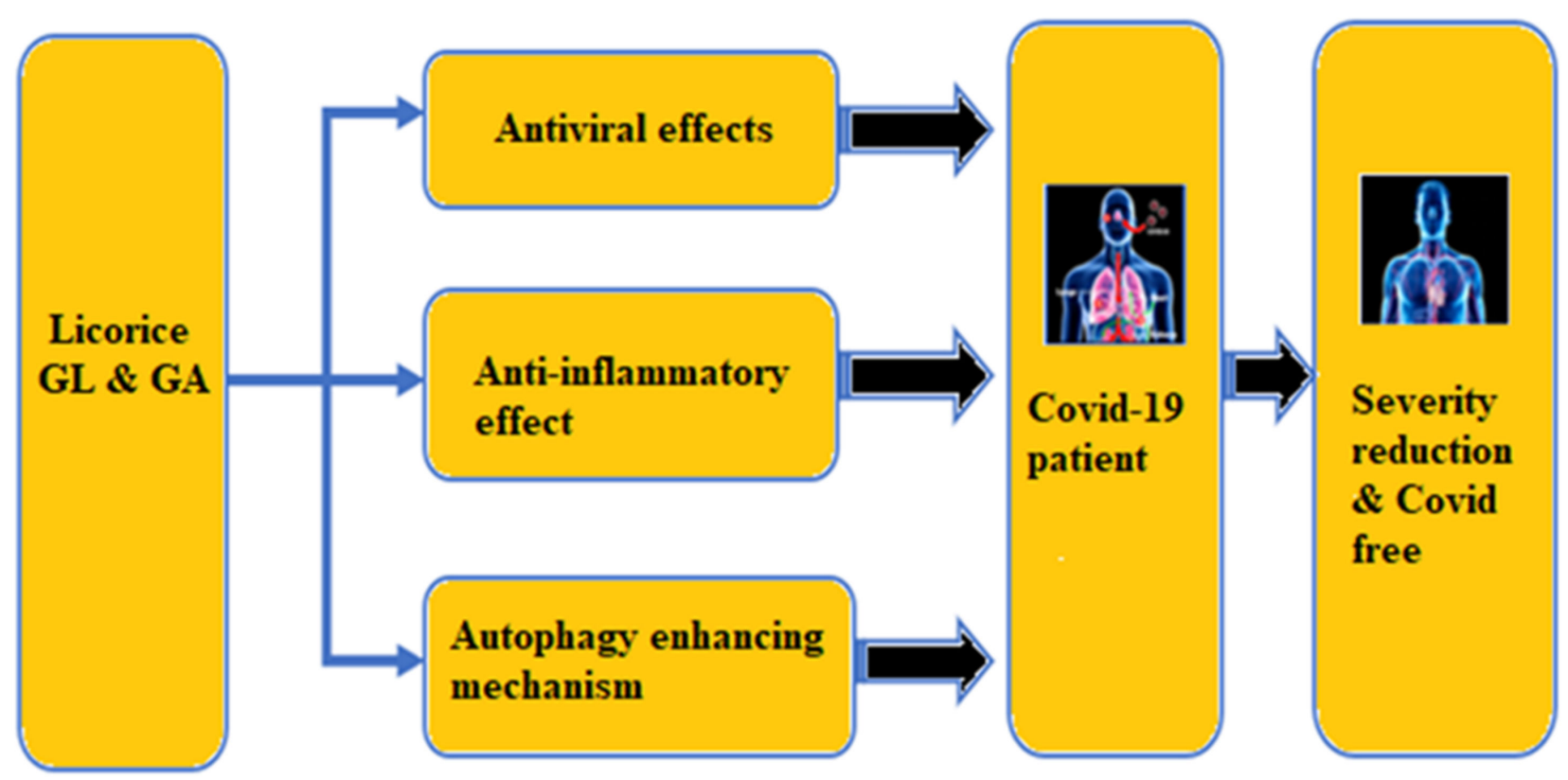

Figure 5. A conceptual diagram showing the effects of licorice on COVID-19 patients.

(i) If any system can block or inhibit the viral replication in the lung epithelial cells, it may be possible to prevent or reduce the body's inflammatory response. Through several studies, it is found that the two triterpenes GL and GA, which are present in licorice, have significant antiviral characteristics against several viruses such as 
Hepatitis A, B, and C, HIV, Coxasackievirus, Influenza virus (H1N1 and H5N1), Duck Hepatitis virus, and SARS-CoV-1. In this respect, it is thus hypothesized that the GL and GA in licorice might prevent the spread of SARS-CoV-2, thereby significantly inhibiting any dangerous inflammatory response.

(ii) Chen and Du [197] conducted a molecular docking test recently and highlighted the potential binding of GL to the ACE-2 molecule. We already knew that SARS-CoV-2 enters the cell through ACE-2. Thus, blocking the ACE-2 by binding with GL can reduce the SARS-CoV-2 infectivity and the resulting COVID-19.

(iii) Autophagy is the suicidal mechanism that an infected cell adopts to protect adjacent cells from further infection., When SARS-CoV-2 infects a cell, the virus will forestall the autophagy mechanism by releasing SKP2 protein that can inhibit the cell's Beclin1 production. Whereas studies have shown that GL in licorice can increase the production of Beclin-1 by a factor of at least two times [107], which may help stimulate the autophagy mechanism and thus inhibit viral replication.

(iv) In the worst case, if the above two mechanisms cannot stop viral replication, there is the potentiality of inflammation in the body. In such a situation, adaptive immunity can be severely compromised, and this is where the phytochemicals in licorice, specifically GL and GA, can significantly reduce inflammation in the body by inhibiting the pro-inflammatory cytokines. In this way, licorice can possibly mitigate the severity of COVID-19 symptoms.

Licorice has a Federal Drug Administration (FDA) rating of 'GRAS' (Generally regarded as safe) [198]. Of interest is that during the first SARS-CoV epidemic in 2002-2003, an oral dose of $300 \mathrm{mg}$ and an intravenous dose of $240 \mathrm{mg}$ were recommended [199]. However, it was found that adverse reactions can result from overuse or overdose of licorice, including excessive $\mathrm{Na}$ ion levels and low $\mathrm{K}$ ions in the body. Such conditions lead to water retention and hypertension, respectively [127]. Heart disease related to excessive daily supplementation has also been reported [200]. It has been found that licorice supplementation can neutralize the intake of other medicines such as warfarin (Coumadin), a common anticoagulant agent $[201,202]$. In addition, it has been recommended that pregnant women limit their intake of licorice; as such, only a few conclusive studies have been conducted. Excessive long-term intake may (i) increase the levels of estrogen in the body and thus may lead to estrogen-mediated cancer and (ii) stimulate the anti-androgenic effect, which may lead to erectile dysfunction [141].

\section{Conclusions}

COVID-19 is spreading across the world with several thousand deaths every day and it is hitting many places as a secondary and tertiary waves. It is understood that if we can evade or alter ARDS, we can avoid the severity and mortality of most COVID-19 patients. A suitable antiviral and anti-inflammatory therapeutical intervention is required for this. Antiviral efficacy, anti-inflammatory property, and stimulation of the autophagy mechanism in cells are licorice properties which have a very high significance for COVID-19 patients. In addition, licorice-based phytochemicals have proven efficacy against a range of bacteria and fungi. Thus, it may be useful to avoid secondary bacterial infection in COVID19 patients and treat other pathogenic diseases. An important corollary of this finding is that, because COVID-19 is of pandemic proportions, a plant-based medicine would be a boon for countries in the Afro-Asian-Pacific regions. Licorice is cheap and plentiful compared to modern allopathic medications, and it could thus make dramatic health improvements in the developing and underdeveloped world. Therefore, it is suggested that researchers should undertake in vitro and in vivo studies with GA and GL against SARS-CoV-2 and, based on the success, move forward with clinical trials, which may help mitigate COVID-19 severity. 
Author Contributions: J.A.: conceptualization: researched the literature and drafted the manuscript. S.F.: contributed to the critical discussion and editing of the manuscript. All authors have read and agreed to the published version of the manuscript.

Funding: The study did not receive any specific grant from funding agencies in the public, commercial, or not-for-profit sectors.

Acknowledgments: The authors are thankful to Federation University Australia for providing the facilities to prepare this article.

Conflicts of Interest: The authors declare that there is no conflict of interest.

\section{References}

1. Worldometer. Coronavirus Cases. Available online: www.worldometers.info/coronoavirus (accessed on 29 August 2021).

2. NDTV. Over 40,000 Vaccinated People Test Positive in Kerala, India: Sources. Media Report. Available online: https://www.ndtv. com/india-news/over-40-000-breakthrough-infections-or-covid-cases-in-vaccinated-people-in-kerala-source-2507884 (accessed on 29 August 2021).

3. India Today. Kerala Reports over 40,000 Breakthrough Covid Cases, Raises Concerns of New Variant. Available online: https:/ / www.indiatoday.in/coronavirus-outbreak/story/kerala-reports-40000-breakthrough-covid-cases-new-variant-1839 476-2021-08-11 (accessed on 29 August 2021).

4. Reuters. Israeli Doctors Find Severe COVID-19 Breakthrough Cases Moslt in Older, Sicker Patients. Available online: https:/ / www.reuters.com/world/middle-east/israeli-doctors-find-severe-covid-19-breakthrough-cases-mostly-older-sicker2021-08-20/ (accessed on 29 August 2021).

5. Precision Vaccinations. Israel's COVID-19 Vaccine Breakthrough Cases Exceeded 50\%. Available online: https://www precisionvaccinations.com/2021/08/11/israels-covid-19-vaccine-breakthrough-cases-exceed-50 (accessed on 29 August 2021).

6. Becker's Hospital Review. Nearly $60 \%$ of Hospitalised COVID-19 Patients in Israel Fully Vaccinated, Data Shows. Available online: https:/ / www.beckershospitalreview.com/public-health/nearly-60-of-hospitalized-covid-19-patients-in-israel-fullyvaccinated-study-finds.html (accessed on 29 August 2021).

7. Musser, J.M.; Christensen, P.A.; Olsen, R.J.; Long, S.W.; Subedi, S.; Davis, J.J.; Gollihar, J.D. Delta variants of SARS-CoV-2 cause significantly increased vaccine breakthrough COVID-19 cases in Houston, Texas. medRxiv 2021. [CrossRef]

8. Birhane, M.; Bressler, S.; Chang, G.; Clark, T.; Dorough, L.; Fischer, M.; Watkins, L.F.; Goldstein, J.M.; Kugeler, K.; COVID-19 Vaccine Breakthrough Case Investigations Team.; et al. COVID-19 Vaccine Breakthrough Infections Reported to CDC-United States, January 1-April 30, 2021. MMWR Morb. Mortal. Wkly. Rep. 2021, 70, 792-793. [CrossRef]

9. Brown, C.M.; Vostok, J.; Johnson, H.; Burns, M.; Gharpure, R.; Sami, S.; Laney, A.S. Outbreak of SARS-CoV-2 infections, including COVID-19 vaccine breakthrough infections, associated with large public gatherings-Barnstable County, Massachusetts, July 2021. MMWR Morb. Mortal. Wkly. Rep. 2021, 70, 1059. [CrossRef] [PubMed]

10. Gupta, N.; Kaur, H.; Yadav, P.D.; Mukhopadhyay, L.; Sahay, R.R.; Kumar, A.; Nyayanit, D.A.; Shete, A.M.; Patil, S.; Majumdar, T.; et al. Clinical Characterization and Genomic Analysis of Samples from COVID-19 Breakthrough Infections during the Second Wave among the Various States of India. Viruses 2021, 13, 1782. [CrossRef]

11. Wang, D.; Hu, B.; Hu, C.; Zhu, F.; Liu, X.; Zhang, J.; Wang, B.; Xiang, H.; Cheng, Z.; Xiong, Y.; et al. Clinical Characteristics of 138 Hospitalized Patients With 2019 Novel Coronavirus-Infected Pneumonia in Wuhan, China. JAMA 2020, 323, 1061-1069. [CrossRef] [PubMed]

12. Mehta, P.; McAuley, D.F.; Brown, M.; Sanchez, E.; Tattersall, R.S.; Manson, J.J. COVID-19: Consider cytokine storm syndromes and immunosuppression. Lancet 2020, 395, 1033-1034. [CrossRef]

13. Haberman, R.; Axelrad, J.; Chen, A.; Castillo, R.; Yan, D.; Izmirly, P.; Neimann, A.; Adhikari, S.; Hudesman, D.; Scher, J.U. Covid-19 in Immune-Mediated Inflammatory Diseases-Case Series from New York. N. Engl. J. Med. 2020, 383, 85-88. [CrossRef] [PubMed]

14. Bryant, A.; Lawrie, T.A.; Dowswell, T.; Fordham, E.J.; Scott, M.; Hill, S.R.; Tham, T.C. Ivermectin for prevention and treatment of COVID-19 infection: A systematic review, meta-analysis and trial sequential analysis to inform clinical guidelines. OSF Prepr. 2021. [CrossRef]

15. Chaccour, C.; Casellas, A.; Matteo, A.B.-D.; Pineda, I.; Fernandez-Montero, A.; Ruiz-Castillo, P.; Richardson, M.-A.; RodríguezMateos, M.; Jordán-Iborra, C.; Brew, J.; et al. The effect of early treatment with ivermectin on viral load, symptoms and humoral response in patients with non-severe COVID-19: A pilot, double-blind, placebo-controlled, randomized clinical trial. EClinicalMedicine 2021, 32, 100720. [CrossRef] [PubMed]

16. Lucchino, B.; Di Franco, M.; Conti, F. COVID-19: An unexpected indication for anti-rheumatic therapies? Rheumatology 2020, 59, 1200-1203. [CrossRef]

17. Kacprzak, K.M. Chemistry and Biology of Cinchona Alkaloids. In Natural Products; Springer: Berlin/Heidelberg, Germany, 2013; pp. 605-641. [CrossRef]

18. Malkinson, F.D. Colchicine. New uses of an old, old drug. Arch. Dermatol. 1982, 118, 453-457. [CrossRef] [PubMed] 
19. Luseba, D.; Elgorashi, E.; Ntloedibe, D.; Van Staden, J. Antibacterial, anti-inflammatory and mutagenic effects of some medicinal plants used in South Africa for the treatment of wounds and retained placenta in livestock. S. Afr. J. Bot. 2007, 73, 378-383. [CrossRef]

20. Soltan, M.M.; Zaki, A.K. Antiviral screening of forty-two Egyptian medicinal plants. J. Ethnopharmacol. 2009, 126, 102-107. [CrossRef] [PubMed]

21. Ben-Shabat, S.; Yarmolinsky, L.; Porat, D.; Dahan, A. Antiviral effect of phytochemicals from medicinal plants: Applications and drug delivery strategies. Drug Deliv. Transl. Res. 2020, 10, 354-367. [CrossRef]

22. Joshi, B.; Sah, G.P.; Basnet, B.B.; Bhatt, M.R.; Sharma, D.; Subedi, K.; Malla, R. Phytochemical extraction and antimicrobial properties of different medicinal plants: Ocimum sanctum (Tulsi), Eugenia caryophyllata (Clove), Achyranthes bidentata (Datiwan) and Azadirachta indica (Neem). J. Microbiol. Antimicrob. 2011, 3, 1-7.

23. Jaiswal, Y.S.; Williams, L.L. A glimpse of Ayurveda-The forgotten history and principles of Indian traditional medicine. J. Tradit. Complement. Med. 2017, 7, 50-53. [CrossRef] [PubMed]

24. Fu, S.; Zhang, J.; Gao, X.; Xia, Y.; Ferrelli, R.M.; Fauci, A.; Guerra, R.; Hu, L. Clinical practice of traditional Chinese medicines for chronic heart failure. Hear Asia 2010, 2, 24-27. [CrossRef] [PubMed]

25. Yang, X.-Y.; Liu, A.-L.; Liu, S.-J.; Xu, X.-W.; Huang, L.-F. Screening for Neuraminidase Inhibitory Activity in Traditional Chinese Medicines Used to Treat Influenza. Molecules 2016, 21, 1138. [CrossRef] [PubMed]

26. Van Wyk, B.E.; Wink, M. Medicinal Plants of the World; CABI: Pretoria, South Africa, 2018.

27. Yarnell, E. Herbs for Upper Digestive Overgrowth of Flora. Altern. Complement. Ther. 2018, 24, 173-179. [CrossRef]

28. Lelešius, R.; Karpovaitè, A.; Mickienè, R.; Drevinskas, T.; Tiso, N.; Ragažinskienè, O.; Kubilienè, L.; Maruška, A.; Šalomskas, A. In vitro antiviral activity of fifteen plant extracts against avian infectious bronchitis virus. BMC Vet. Res. 2019, 15, 178. [CrossRef]

29. Fiore, C.; Eisenhut, M.; Ragazzi, E.; Zanchin, G.; Armanini, D. A history of the therapeutic use of liquorice in Europe. J. Ethnopharmacol. 2005, 99, 317-324. [CrossRef] [PubMed]

30. Halberstein, R.A. Medicinal Plants: Historical and Cross-Cultural Usage Patterns. Ann. Epidemiol. 2005, 15, 686-699. [CrossRef] [PubMed]

31. Pan, S.-Y.; Litscher, G.; Gao, S.-H.; Zhou, S.-F.; Yu, Z.-L.; Chen, H.-Q.; Zhang, S.-F.; Tang, M.-K.; Sun, J.-N.; Ko, K.-M. Historical Perspective of Traditional Indigenous Medical Practices: The Current Renaissance and Conservation of Herbal Resources. Evid.-Based Complement. Altern. Med. 2014, 2014, 525340. [CrossRef]

32. Mwitari, P.G.; Ayeka, P.A.; Ondicho, J.; Matu, E.N.; Bii, C.C. Antimicrobial Activity and Probable Mechanisms of Action of Medicinal Plants of Kenya: Withania somnifera, Warbugia ugandensis, Prunus africana and Plectrunthus barbatus. PLoS ONE 2013, 8, e65619. [CrossRef] [PubMed]

33. Noor, A.; Bansal, V.S.; Vijayalakshmi, M.A. Current update on anti-diabetic biomolecules from key traditional Indian medicinal plants. Curr. Sci. 2013, 104, 721-727.

34. Aggarwal, B.B.; Prasad, S.; Reuter, S.; Kannappan, R.; Yadav, V.R.; Park, B.; Kim, J.H.; Gupta, S.C.; Phromnoi, K.; Sundaram, C.; et al. Identification of Novel Anti-inflammatory Agents from Ayurvedic Medicine for Prevention of Chronic Diseases: "Reverse Pharmacology" and "Bedside to Bench" Approach. Curr. Drug Targets 2011, 12, 1595-1653. [CrossRef]

35. Smith, J.V.; Burdick, A.J.; Golik, P.; Khan, I.; Wallace, U.; Luo, Y. Anti-apoptotic properties of Ginkgo biloba extract EGb 761 in differentiated PC12 cells. Cell. Mol. Boil. 2002, 48, 699-707.

36. Li, W.; Mo, W.; Shen, D.; Sun, L.; Wang, J.; Lu, S.; Gitschier, J.M.; Zhou, B. Yeast Model Uncovers Dual Roles of Mitochondria in the Action of Artemisinin. PLoS Genet. 2005, 1, e36. [CrossRef]

37. Wallace, D.C. Anecdotal, historical and critical commentaries on genetics: Mitochondria as chi. Genetics 2008, 179, 727-735. [CrossRef] [PubMed]

38. Kumar, S.; Dobos, G.J.; Rampp, T. The Significance of Ayurvedic Medicinal Plants. J. Evid.-Based Integr. Med. 2017, 22, 494-501. [CrossRef]

39. Selitrennikoff, C.P. Antifungal Proteins. Appl. Environ. Microbiol. 2001, 67, 2883-2894. [CrossRef] [PubMed]

40. Asres, K.; Bucar, F. Anti-HIV activity against immunodeficiency virus type 1 (HIV-I) and type II (HIV-II) of compounds isolated from the stem bark of Combretum molle. Ethiop. Med. J. 2005, 43, 15-20. [PubMed]

41. Ghildiyal, R.; Prakash, V.; Chaudhary, V.; Gupta, V.; Gabrani, R. Phytochemicals as antiviral agents: Recent updates. In Plant-Derived Bioactives; Springer: Berlin/Heidelberg, Germany, 2020; pp. 279-295. [CrossRef]

42. Ho, T.-Y.; Wu, S.-L.; Chen, J.-C.; Li, C.-C.; Hsiang, C.-Y. Emodin blocks the SARS coronavirus spike protein and angiotensinconverting enzyme 2 interaction. Antivir. Res. 2007, 74, 92-101. [CrossRef]

43. McCutcheon, A.; Roberts, T.; Gibbons, E.; Ellis, S.; Babiuk, L.; Hancock, R.; Towers, G. Antiviral screening of British Columbian medicinal plants. J. Ethnopharmacol. 1995, 49, 101-110. [CrossRef]

44. Lou, S.D. Research on Anti-HIV Activities of Chinese Herbal Medicines; Yunnan Science and Technology: Kunming, China, 1998.

45. Li, S.-Y.; Chen, C.; Zhang, H.-Q.; Guo, H.-Y.; Wang, H.; Wang, L.; Zhang, X.; Hua, S.-N.; Yu, J.; Xiao, P.-G.; et al. Identification of natural compounds with antiviral activities against SARS-associated coronavirus. Antivir. Res. 2005, 67, 18-23. [CrossRef] [PubMed]

46. Selitrennikoff, C.P. Influenza virus variants with reduced susceptibility to inhibition by a polyphenol extract from Geranium sanguineum L. Die Pharm. Int. J. Pharm. Sci. 2003, 58, 53-57. [CrossRef] 
47. Tolo, F.M.; Rukunga, G.M.; Muli, F.W.; Njagi, E.N.; Njue, W.; Kumon, K.; Mungai, G.M.; Muthaura, C.N.; Muli, J.M.; Keter, L.K.; et al. Anti-viral activity of the extracts of a Kenyan medicinal plant Carissa edulis against herpes simplex virus. J. Ethnopharmacol. 2006, 104, 92-99. [CrossRef] [PubMed]

48. Lubbe, A.; Seibert, I.; Klimkait, T.; van der Kooy, F. Ethnopharmacology in overdrive: The remarkable anti-HIV activity of Artemisia annua. J. Ethnopharmacol. 2012, 141, 854-859. [CrossRef]

49. Huang, X.; Ding, L.; Yang, J.; Bian, X.-J.; Zhang, L.-Y.; Zhang, Z.-X.; Liu, G.-Y. Study on the pharmacokinetics of diammonium glycyrrhizinate capsule in healthy volunteers by HPLC-MS. Chin. J. Clin. Pharmacol. 2006, 22, 365.

50. Debiaggi, M.; Pagani, L.; Cereda, P.M.; Landini, P.; Romero, E. Antiviral activity of Chamaecyparis lawsoniana extract: Study with herpes simplex virus type 2. Microbiologica 1988, 11, 55-61.

51. Vieira, R.F.; Bizzo, H.R.; Deschamps, C. Genetic resources of aromatic plants from Brazil. Isr. J. Plant Sci. 2010, 58, 263-271. [CrossRef]

52. Akram, M.; Tahir, I.M.; Shah, S.M.A.; Mahmood, Z.; Altaf, A.; Ahmad, K.; Munir, N.; Daniyal, M.; Nasir, S.; Mehboob, H. Antiviral potential of medicinal plants against HIV, HSV, influenza, hepatitis, and coxsackievirus: A systematic review. Phytother. Res. 2018, 32, 811-822. [CrossRef]

53. Dhama, K.; Karthik, K.; Khandia, R.; Munjal, A.; Tiwari, R.; Rana, R.; Khurana, S.K.; Ullah, S.; Khan, R.U.; Alagawany, M.; et al. Medicinal and therapeutic potential of herbs and plant metabolites/extracts countering viral pathogens-current knowledge and future prospects. Curr. Drug Metab. 2018, 19, 236-263. [CrossRef] [PubMed]

54. Wink, M. Potential of DNA Intercalating Alkaloids and Other Plant Secondary Metabolites against SARS-CoV-2 Causing COVID-19. Diversity 2020, 12, 175. [CrossRef]

55. Dioscorides. De Materia Medica. 1555. Available online: http://bdh.bne.es/bnesearch/detalle/bdh0000037225 (accessed on 25 September 2021).

56. Fiore, C.; Eisenhut, M.; Krausse, R.; Ragazzi, E.; Pellati, D.; Armanini, D.; Bielenberg, J. Antiviral effects ofGlycyrrhiza species. Phytother. Res. Int. J. Devoted Pharmacol. Toxicol. Eval. Nat. Prod. Deriv. 2008, 22, 141-148. [CrossRef] [PubMed]

57. Wang, L.; Yang, R.; Yuan, B.; Liu, Y.; Liu, C. The antiviral and antimicrobial activities of licorice, a widely-used Chinese herb. Acta Pharm. Sin. B 2015, 5, 310-315. [CrossRef] [PubMed]

58. Gupta, V.K.; Fatima, A.; Faridi, U.; Negi, A.S.; Shanker, K.; Kumar, J.; Rahuja, N.; Luqman, S.; Sisodia, B.S.; Saikia, D.; et al. Antimicrobial potential of Glycyrrhiza glabra roots. J. Ethnopharmacol. 2008, 116, 377-380. [CrossRef]

59. Aly, A.M.; Al-Alousi, L.; Salem, H.A. Licorice: A possible anti-inflammatory and anti-ulcer drug. AAPS PharmSciTech 2005, 6, E74-E82. [CrossRef]

60. Hanrahan, C. Gale Encyclopedia of Alternative Medicine, Licorice [CD-ROM]; Thomson Gale: Farmington Hills, MI, USA, 2001.

61. Lust, J. The Herb Book; Bantam Books: New York, NY, USA, 1994.

62. Yang, R.; Yuan, B.-C.; Ma, Y.-S.; Zhou, S.; Liu, Y. The anti-inflammatory activity of licorice, a widely used Chinese herb. Pharm. Biol. 2016, 55, 5-18. [CrossRef] [PubMed]

63. Ayurvedic Pharmacopoeia of India. Vol. I: Part I, Department of Ayush, Ministry of Health and Family Welfare; Government of India: New Delhi, India, 2001.

64. Obolentseva, G.V.; Litvinenko, I.V.I.; ammosov, A.S.; Popova, T.P.; Sampiev, A.M. Pharmacological and therapeutic properties of licorice preparations-A Review (Translated from Khimiko-Farmatsevticheskii Zhurnal). Med. Plants 1999, 33, 24-31. Available online: https:/ / fdocuments.in/document/pharmacological-and-therapeutic-properties-of-licorice-preparations-a-review.html (accessed on 17 August 2021).

65. RPRM. Resources of Plant Raw Materials in the USSR: Flowering Plants, Their Chemical Compositions, and Use; Nauka: Moscow, Russia, 1987.

66. Somjen, D.; Tamir, S.; Vaya, J. Estrogen-Like Activity of Licorice Root Extract and Its Constituents. Oxidative Stress Dis. 2004, 14, 615-634. [CrossRef]

67. Van Rossum, T.G.; Vulto, A.G.; Hop, W.C.; Brouwer, J.T.; Niesters, H.; Schalm, S.W. Intravenous glycyrrhizin for the treatment of chronic hepatitis C: A double-blind, randomized, placebo-controlled phase I/II trial. J. Gastroenterol. Hepatol. 1999, 14, 1093-1099. [CrossRef] [PubMed]

68. Bahmani, M.; Rafieian-Kopaei, M.; Jeloudari, M.; Eftekhari, Z.; Delfan, B.; Zargaran, A.; Forouzan, S. A review of the health effects and uses of drugs of plant licorice (Glycyrrhiza glabra L.) in Iran. Asian Pac. J. Trop. Dis. 2014, 4, S847-S849. [CrossRef]

69. Zang, Y. Pharmacological Activities of Coumarin Compounds in Licorice: A Review. Nat. Prod. Commun. 2020, 15. [CrossRef]

70. Badkhane, Y.; Yadav, A.S.; Bajaj, A.; Sharma, A.K.; Raghuwanshi, D.K. Glycyrrhiza glabra L. a miracle medicinal herb. Indo Am. J. Pharm. Res. 2014, 4, 5808-5816.

71. Dhingra, D.; Sharma, A. Evaluation of antidepressant-like activity of glycyrrhizin in mice. Indian J. Pharmacol. 2005, 37, 390. [CrossRef]

72. Fuhrman, B.; Volkova, N.; Kaplan, M.; Presser, D.; Attias, J.; Hayek, T.; Aviram, M. Antiatherosclerotic effects of licorice extract supplementation on hypercholesterolemic patients: Increased resistance of LDL to atherogenic modifications, reduced plasma lipid levels, and decreased systolic blood pressure. Nutrition 2002, 18, 268-273. [CrossRef]

73. Armanini, D.; De Palo, C.B.; Mattarello, M.J.; Spinella, P.; Zaccaria, M.; Ermolao, A.; Palermo, M.; Fiore, C.; Sartorato, P.; Francini-Pesenti, F.; et al. Effect of licorice on the reduction of body fat mass in healthy subjects. J. Endocrinol. Investig. 2003, 26, 646-650. [CrossRef] [PubMed] 
74. Jung, J.-C.; Lee, Y.-H.; Kim, S.H.; Kim, K.-J.; Kim, K.-M.; Oh, S.; Jung, Y.-S. Hepatoprotective effect of licorice, the root of Glycyrrhiza uralensis Fischer, in alcohol-induced fatty liver disease. BMC Complement. Altern. Med. 2015, 16, 19. [CrossRef] [PubMed]

75. Thakur, V.; Nargis, S.; Gonzalez, M.; Pradhan, S.; Terreros, D.; Chattopadhyay, M. Role of Glycyrrhizin in the Reduction of Inflammation in Diabetic Kidney Disease. Nephron 2017, 137, 137-147. [CrossRef]

76. Li, X.; Sun, R.; Liu, R. Natural products in licorice for the therapy of liver diseases: Progress and future opportunities. Pharmacol. Res. 2019, 144, 210-226. [CrossRef]

77. Armanini, D.; Fiore, C.; Mattarello, M.J.; Bielenberg, J.; Palermo, M. History of the Endocrine Effects of Licorice. Exp. Clin. Endocrinol. Diabetes 2002, 110, 257-261. [CrossRef]

78. Li, Y.-J.; Chen, J.; Li, Y.; Li, Q.; Zheng, Y.-F.; Fu, Y.; Li, P. Screening and characterization of natural antioxidants in four Glycyrrhiza species by liquid chromatography coupled with electrospray ionization quadrupole time-of-flight tandem mass spectrometry. $J$. Chromatogr. A 2011, 1218, 8181-8191. [CrossRef] [PubMed]

79. Liu, H.; Wang, J.; Zhou, W.; Wang, Y.; Yang, L. Systems approaches and polypharmacology for drug discovery from herbal medicines: An example using licorice. J. Ethnopharmacol. 2013, 146, 773-793. [CrossRef]

80. Miyake, K.; Tango, T.; Ota, Y.; Mitamura, K.; Yoshiba, M.; Kako, M.; Hayashi, S.; Ikeda, Y.; Hayashida, N.; Iwabuchi, S.; et al. Efficacy of Stronger Neo-Minophagen C compared between two doses administered three times a week on patients with chronic viral hepatitis. J. Gastroenterol. Hepatol. 2002, 17, 1198-1204. [CrossRef] [PubMed]

81. Takahara, T.; Watanabe, A.; Shiraki, K. Effects of glycyrrhizin on hepatitis B surface antigen: A biochemical and morphological study. J. Hepatol. 1994, 21, 601-609. [CrossRef]

82. Zhang, L.; Wang, B.; Coordinating Group of SNMC Trial's Society of Hepatology in China. Randomized clinical trial with two doses (100 and $40 \mathrm{ml}$ ) of Stronger Neo-Minophagen C in Chinese patients with chronic hepatitis B. Hepatol. Res. 2002, 24, 220-227. [CrossRef]

83. Celik, M.M.; Duran, N. An experimental in-vitro study to evaluate the anti-helicobacter activity of Glycyrrhetinic acid. Rev. Romana Med. Lab. 2019, 27, 63-71. [CrossRef]

84. Long, D.R.; Mead, J.; Hendricks, J.M.; Hardy, M.E.; Voyich, J.M. 18bGlycyrrhetinic acid inhibits methicillin-resistant Staphylococcus aureus survival and attenuates virulence gene expression. Antimicrob. Agents Chemother. 2013, 57, 241-247. [CrossRef] [PubMed]

85. Krausse, R.; Bielenberg, J.; Blaschek, W.; Ullmann, U. In vitro anti-Helicobacter pylori activity of Extractum liquiritiae, glycyrrhizin and its metabolites. J. Antimicrob. Chemother. 2004, 54, 243-246. [CrossRef]

86. Kolbe, L.; Immeyer, J.; Batzer, J.; Wensorra, U.; Dieck, K.T.; Mundt, C.; Wolber, R.; Stäb, F.; Schönrock, U.; Ceilley, R.I.; et al. Anti-inflammatory efficacy of Licochalcone A: Correlation of clinical potency and in vitro effects. Arch. Dermatol. Res. 2006, 298, 23-30. [CrossRef]

87. Kwon, H.-J.; Kim, H.-H.; Ryu, Y.B.; Kim, J.H.; Jeong, H.J.; Lee, S.-W.; Chang, J.S.; Cho, K.-O.; Rho, M.-C.; Park, S.-J.; et al. In vitro anti-rotavirus activity of polyphenol compounds isolated from the roots of Glycyrrhizauralensis. Bioorg. Med. Chem. 2010, 18, 7668-7674. [CrossRef]

88. Al-Turki, A.I.; El-Ziney, M.G.; Abdel-Salam, A.M. Chemical and antibacterial characterization of aqueous extracts of oregano, marjoram, sage and licorice and their application in milk and labneh. J. Food Agric. Environ. 2008, 6, 39-44.

89. Park, I.-K.; Kim, J.; Lee, Y.-S.; Shin, S.-C. In vivofungicidal activity of medicinal plant extracts against six phytopathogenic fungi. Int. J. Pest Manag. 2008, 54, 63-68. [CrossRef]

90. Messier, C.; Grenier, D. Effect of licorice compounds licochalcone A, glabridin and glycyrrhizic acid on growth and virulence properties of Candida albicans. Mycoses 2011, 54, e801-e806. [CrossRef]

91. Maas, H.; Cock, I.E. The Interactive Antimicrobial Activity of Glycyrrhiza glabra L. Root Extracts and Conventional Antibiotics Against some Bacterial Triggers of Autoimmune Inflammatory Diseases. Pharmacogn. Commun. 2018, 8, 66-74. [CrossRef]

92. Wu, S.-C.; Yang, Z.-Q.; Liu, F.; Peng, W.-J.; Qu, S.-Q.; Li, Q.; Song, X.-B.; Zhu, K.; Shen, J.-Z. Antibacterial Effect and Mode of Action of Flavonoids from Licorice against Methicillin-Resistant Staphylococcus aureus. Front. Microbiol. 2019, $10,2489$. [CrossRef] [PubMed]

93. Chung, J.G. Inhibitory Actions of Glycyrrhizic Acid on Arylamine N-Acetyltransferase Activity in Strains of Helicobacter Pylori from Peptic Ulcer Patients. Drug Chem. Toxicol. 1998, 21, 355-370. [CrossRef] [PubMed]

94. Pastorino, G.; Cornara, L.; Soares, S.; Rodrigues, F.; Oliveira, M.B.P.P. Liquorice (Glycyrrhiza glabra): A phytochemical and pharmacological review. Phytother. Res. 2018, 32, 2323-2339. [CrossRef] [PubMed]

95. Fukai, T.; Marumo, A.; Kaitou, K.; Kanda, T.; Terada, S.; Nomura, T. Antimicrobial activity of licorice flavonoids against methicillin-resistant Staphylococcus aureus. Fitoter 2002, 73, 536-539. [CrossRef]

96. Demizu, S.; Kajiyama, K.; Takahashi, K.; Hiraga, Y.; Yamamoto, S.; Tamura, Y.; Okada, K.; Kinoshita, T. Antioxidant and antimicrobial constituents of licorice: Isolation and structure elucidation of a new benzofuran derivative. Chem. Pharm. Bull. 1988, 36, 3474-3479. [CrossRef] [PubMed]

97. Haraguchi, H.; Tanimoto, K.; Tamura, Y.; Mizutani, K.; Kinoshita, T. Mode of antibacterial action of retrochalcones from Glycyrrhiza inflata. Phytochemistry 1998, 48, 125-129. [CrossRef]

98. Zhou, T. Antimicrobial Activity of Licochalcone E against Staphylococcus aureus and Its Impact on the Production of Staphylococcal Alpha-Toxin. J. Microbiol. Biotechnol. 2012, 22, 800-805. [CrossRef] [PubMed] 
99. Fukai, T.; Marumo, A.; Kaitou, K.; Kanda, T.; Terada, S.; Nomura, T. Anti-Helicobacter pylori flavonoids from licorice extract. Life Sci. 2002, 71, 1449-1463. [CrossRef]

100. Pompei, R.; Flore, O.; Marccialis, M.A.; Pani, A.; Loddo, B. Glycyrrhizic acid inhibits virus growth and inactivates virus particles. Nat. Cell Biol. 1979, 281, 689-690. [CrossRef] [PubMed]

101. Matsumoto, Y.; Matsuura, T.; Aoyagi, H.; Matsuda, M.; Hmwe, S.S.; Date, T.; Watanabe, N.; Watashi, K.; Suzuki, R.; Ichinose, S.; et al. Antiviral Activity of Glycyrrhizin against Hepatitis C Virus In Vitro. PLoS ONE 2013, 8, e68992. [CrossRef]

102. Ashfaq, U.A.; Masoud, M.S.; Nawaz, Z.; Riazuddin, S. Glycyrrhizin as antiviral agent against Hepatitis C Virus. J. Transl. Med. 2011, 9, 112. [CrossRef]

103. Huang, W.; Chen, X.; Li, Q.; Li, P.; Zhao, G.; Xu, M.; Xie, P. Inhibition of Intercellular Adhesion in Herpex Simplex Virus Infection by Glycyrrhizin. Cell Biophys. 2011, 62, 137-140. [CrossRef] [PubMed]

104. Michaelis, M.; Geiler, J.; Naczk, P.; Sithisarn, P.; Ogbomo, H.; Altenbrandt, B.; Leutz, A.; Doerr, H.W.; Cinatl, J., Jr. Glycyrrhizin inhibits highly pathogenic H5N1 influenza A virus-induced pro-inflammatory cytokine and chemokine expression in human macrophages. Med. Microbiol. Immunol. 2010, 199, 291-297. [CrossRef] [PubMed]

105. Moisy, D.; Avilov, S.V.; Jacob, Y.; Laoide, B.M.; Ge, X.; Baudin, F.; Naffakh, N.; Jestin, J.-L. HMGB1 Protein Binds to Influenza Virus Nucleoprotein and Promotes Viral Replication. J. Virol. 2012, 86, 9122-9133. [CrossRef]

106. Smirnov, V.S.; Zarubaev, V.V.; Anfimov, P.M.; Shtro, A.A. Effect of a combination of glutamyl-tryptophan and glycyrrhizic acid on the course of acute infection caused by influenza (H3H2) virus in mice. Vopr. Virusol. 2012, 57, 23-27. [PubMed]

107. Laconi, S.; Madeddu, M.A.; Pompei, R. Autophagy Activation and Antiviral Activity by a Licorice Triterpene. Phytother. Res. 2014, 28, 1890-1892. [CrossRef]

108. Soufy, H.; Yassein, S.; Ahmed, A.R.; Khodier, M.H.; Kutkat, M.; Nasr, S.M.; Okda, F. Antiviral and immune stimulant activities of glycyrrhizin against duck hepatitis virus. Afr. J. Tradit. Complement. Altern. Med. 2012, 9, 389-395. [CrossRef]

109. Fukuchi, K.; Okudaira, N.; Adachi, K.; Odai-Ide, R.; Watanabe, S.; Ohno, H.; Yamamoto, M.; Kanamoto, T.; Terakubo, S.; Nakashima, H.; et al. Antiviral and Antitumor Activity of Licorice Root Extracts. In Vivo 2016, 30, 777-786. [CrossRef] [PubMed]

110. Hoever, G.; Baltina, L.; Michaelis, M.; Kondratenko, R.; Baltina, L.; Tolstikov, G.A.; Doerr, H.W.; Cinatl, J. Antiviral Activity of Glycyrrhizic Acid Derivatives against SARS-Coronavirus. J. Med. Chem. 2005, 48, 1256-1259. [CrossRef] [PubMed]

111. Cinatl, J.; Morgenstern, B.; Bauer, G.; Chandra, P.; Rabenau, H.; Doerr, H. Glycyrrhizin, an active component of liquorice roots, and replication of SARS-associated coronavirus. Lancet 2003, 361, 2045-2046. [CrossRef]

112. Murray, M.T. Glycyrrhiza glabra (Licorice). In Textbook of Natural Medicine; Elsevier: Amsterdam, The Netherlands, 2020; pp. 641-647.e3.

113. Crance, J.M.; Biziagos, E.; Passagot, J.; van Cuyck-Gandré, H.; Deloince, R. Inhibition of hepatitis A virus replication in vitro by antiviral compounds. J. Med. Virol. 1990, 31, 155-160. [CrossRef]

114. Sato, H.; Goto, W.; Yamamura, J.-I.; Kurokawa, M.; Kageyama, S.; Takahara, T.; Watanabe, A.; Shiraki, K. Therapeutic basis of glycyrrhizin on chronic hepatitis B. Antivir. Res. 1996, 30, 171-177. [CrossRef]

115. Tandon, A. Treatment of subacute hepatitis with Lamivudine and intravenous Glycyrrhizin: A pilot study. Hepatol. Res. 2001, 20, 1-8. [CrossRef]

116. Orlent, H.; Hansen, B.; Willems, M.; Brouwer, J.T.; Huber, R.; Kullak-Ublick, G.A.; Gerken, G.; Zeuzem, S.; Nevens, F.; Tielemans, W.C.; et al. Biochemical and histological effects of 26 weeks of glycyrrhizin treatment in chronic hepatitis C: A randomized phase II trial. J. Hepatol. 2006, 45, 539-546. [CrossRef]

117. Ikeda, K. Glycyrrhizin injection therapy prevents hepatocellular carcinogenesis in patients with interferon-resistant active chronic hepatitis C. Hepatol. Res. 2007, 37, S287-S293. [CrossRef] [PubMed]

118. De Clercq, E. Current lead natural products for the chemotherapy of human immunodeficiency virus (HIV) infection. Med. Res. Rev. 2000, 20, 323-349. [CrossRef]

119. Sasaki, H.; Takei, M.; Kobayashi, M.; Pollard, R.B.; Suzuki, F. Effect of Glycyrrhizin, an Active Component of Licorice Roots, on HIV Replication in Cultures of Peripheral Blood Mononuclear Cells from HIV-Seropositive Patients. Pathobiology 2002, 70, 229-236. [CrossRef]

120. Harada, S. The broad anti-viral agent glycyrrhizin directly modulates the fluidity of plasma membrane and HIV-1 envelope. Biochem. J. 2005, 392, 191-199. [CrossRef]

121. Baba, M.; Shigeta, S. Antiviral activity of glycyrrhizin against varicella-zoster virus in vitro. Antivir. Res. 1987, 7, 99-107. [CrossRef]

122. Lin, J.-C. Mechanism of action of glycyrrhizic acid in inhibition of Epstein-Barr virus replication in vitro. Antivir. Res. 2003, 59, 41-47. [CrossRef]

123. Numazaki, K.; Nagata, N.; Sato, T.; Chiba, S. Effect of glycyrrhizin, cyclosporin A, and tumor necrosis factor $\alpha$ on infection of U-937 and MRC-5 cells by human cytomegalovirus. J. Leukoc. Biol. 1994, 55, 24-28. [CrossRef]

124. Zhang, H.; Song, Y.; Zhang, Z. Glycyrrhizin Administration Ameliorates Coxsackievirus B3-Induced Myocarditis in Mice. Am. J. Med. Sci. 2012, 344, 206-210. [CrossRef] [PubMed]

125. Lampis, G.; Deidda, D.; Pinza, M.; Pompei, R. Enhancement of Anti-Herpetic Activity of Glycyrrhizic Acid by Physiological Proteins. Antivir. Chem. Chemother. 2001, 12, 125-131. [CrossRef] [PubMed]

126. Hardy, R.S.; Raza, K.; Cooper, M.S. Endogenous glucocorticoids in inflammation: Contributions of systemic and local responses. Swiss Med. Wkl. 2012, 142, w13650. [CrossRef] 
127. Utsunomiya, T.; Kobayashi, M.; Pollard, R.B.; Suzuki, F. Glycyrrhizin, an active component of licorice roots, reduces morbidity and mortality of mice infected with lethal doses of influenza virus. Antimicrob. Agents Chemother. 1997, 41, 551-556. [CrossRef] [PubMed]

128. Sekizawa, T.; Yanagi, K.; Itoyama, Y. Glycyrrhizin increases survival of mice with herpes simplex encephalitis. Acta Virol. 2001, 45, 51-54. [PubMed]

129. Lu, H.; Huo, N.; Wang, G.; Li, H.; Nie, L.; Xu, X. Clinical observation of therapeutic effect of compound glycyrrhizin on SARS. China Pharm. 2003, 10, 34-36.

130. Wu, H.B.; Li, H.M.; Lu, C.A.; Gao, Y.J.; Li, X.Q.; Zhou, A.X. Experimental study on Shuanghuanglian dispersible tablets against viruses. Chin. J. Exp. Tradit. Med. Formul. 2004, 10, 48-50.

131. Yang, H.; Ko, H.-J.; Yang, J.-Y.; Kim, J.-J.; Seo, S.-U.; Park, S.G.; Choi, S.S.; Seong, J.K.; Kweon, M.-N. Interleukin-1 Promotes Coagulation, Which Is Necessary for Protective Immunity in the Lung against Streptococcus pneumoniae Infection. J. Infect. Dis. 2012, 207, 50-60. [CrossRef]

132. Krishnaswamy, K. Traditional Indian spices and their health significance. Asia Pac. J. Clin. Nutr. 2008, 17, 265-268. [PubMed]

133. Tapsell, L.C.; Hemphill, I.; Cobiac, L.; Sullivan, D.R.; Fenech, M.; Patch, C.S.; Roodenrys, S.; Keogh, J.; Clifton, P.; Williams, P.; et al Health benefits of herbs and spices: The past, the present, the future. Med. J. Aust. 2006, 185 (Suppl. 5), S1-S24. [CrossRef] [PubMed]

134. Mueller, M.; Hobiger, S.; Jungbauer, A. Anti-inflammatory activity of extracts from fruits, herbs and spices. Food Chem. 2010, 122, 987-996. [CrossRef]

135. Hanada, T.; Yoshimura, A. Regulation of cytokine signaling and inflammation. Cytokine Growth Factor Rev. 2002, 13, 413-421. [CrossRef]

136. Guo, J.; Shang, E.; Zhao, J.; Fan, X.; Duan, J.; Qian, D.; Tao, W.; Tang, Y. Data mining and frequency analysis for licorice as a "on Chinese Formulae Database" herb in Chinese Formulae based on Chinese Formulae. Phytomedicine 2014, 21, 1281-1286. [CrossRef]

137. Murray, M.T. The Healing Power of Herbs, 2nd ed.; Three Rivers Press: New York, NY, USA, 1995.

138. Szapary P.O. Tyler's Herbs of Choice: The Therapeutic Use of Phytomedicinals; Robberts, J.E., Tyler, V.E., Eds.; Haworth Herbal: Binghamton, NY, USA, 1999; ISBN 0789001608. [CrossRef]

139. Wu, T.-Y.; Khor, T.O.; Saw, C.; Loh, S.C.; Chen, A.I.; Lim, S.S.; Park, J.H.Y.; Cai, L.; Kong, A.-N.T. Anti-inflammatory/Antioxidative Stress Activities and Differential Regulation of Nrf2-Mediated Genes by Non-Polar Fractions of Tea Chrysanthemum zawadskii and Licorice Glycyrrhiza uralensis. AAPS J. 2010, 13, 1-13. [CrossRef]

140. Chandrasekaran, C.V.; Deepak, H.B.; Thiyagarajan, P.; Kathiresan, S.; Sangli, G.K.; Deepak, M.; Agarwal, A. Dual inhibitory effect of Glycyrrhiza glabra (GutGardTM) on COX and LOX products. Phytomedicine 2011, 18, 278-284. [CrossRef]

141. Kao, T.-C.; Wu, C.-H.; Yen, G.-C. Bioactivity and Potential Health Benefits of Licorice. J. Agric. Food Chem. 2014, 62, 542-553. [CrossRef] [PubMed]

142. Yu, J.-Y.; Ha, J.Y.; Kim, K.-M.; Jung, Y.-S.; Jung, J.-C.; Oh, S. Anti-Inflammatory Activities of Licorice Extract and Its Active Compounds, Glycyrrhizic Acid, Liquiritin and Liquiritigenin, in BV2 Cells and Mice Liver. Molecules 2015, 20, 13041-13054. [CrossRef] [PubMed]

143. Xia, S.; Li, X.; Johnson, T.; Seidel, C.; Wallace, D.P.; Li, R. Polycystin-dependent fluid flow sensing targets histone deacetylase 5 to prevent the development of renal cysts. Development 2010, 137, 1075-1084. [CrossRef] [PubMed]

144. Wang, C.-Y.; Kao, T.-C.; Lo, W.-H.; Yen, G.-C. Glycyrrhizic Acid and 18ß-Glycyrrhetinic Acid Modulate Lipopolysaccharide-

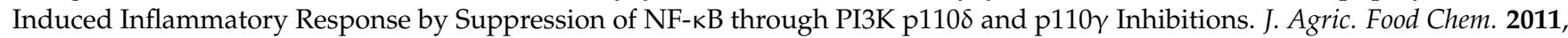
59, 7726-7733. [CrossRef] [PubMed]

145. Bai, M.; Yao, G.-D.; Ren, Q.; Li, Q.; Liu, Q.-B.; Zhang, Y.; Wang, X.-B.; Huang, X.-X.; Song, S.-J. Triterpenoid saponins and flavonoids from licorice residues with anti-inflammatory activity. Ind. Crops Prod. 2018, 125, 50-58. [CrossRef]

146. Frattaruolo, L.; Carullo, G.; Brindisi, M.; Mazzotta, S.; Bellissimo, L.; Rago, V.; Curcio, R.; Dolce, V.; Aiello, F.; Cappello, A.R. Antioxidant and Anti-Inflammatory Activities of Flavanones from Glycyrrhiza glabra L. (licorice) Leaf Phytocomplexes: Identification of Licoflavanone as a Modulator of NF-kB/MAPK Pathway. Antioxidants 2019, 8, 186. [CrossRef]

147. Xiao, Y.; Xu, J.; Mao, C.; Jin, M.; Wu, Q.; Zou, J.; Gu, Q.; Zhang, Y.; Zhang, Y. 18ß-Glycyrrhetinic Acid Ameliorates Acute Propionibacterium acnes-induced Liver Injury through Inhibition of Macrophage Inflammatory Protein-1 $\alpha$. J. Biol. Chem. 2010, 285, 1128-1137. [CrossRef] [PubMed]

148. Wang, X.-R.; Hao, H.-G.; Chu, L. Glycyrrhizin inhibits LPS-induced inflammatory mediator production in endometrial epithelial cells. Microb. Pathog. 2017, 109, 110-113. [CrossRef] [PubMed]

149. Ishida, T.; Miki, I.; Tanahashi, T.; Yagi, S.; Kondo, Y.; Inoue, J.; Kawauchi, S.; Nishiumi, S.; Yoshida, M.; Maeda, H.; et al. Effect of $18 \beta$-glycyrrhetinic acid and hydroxypropyl $\gamma$ cyclodextrin complex on indomethacin-induced small intestinal injury in mice. Eur. J. Pharmacol. 2013, 714, 125-131. [CrossRef] [PubMed]

150. Kim, Y.W.; Ki, S.H.; Lee, J.R.; Lee, S.J.; Kim, C.W.; Kim, S.C.; Kim, S.G. Liquiritigenin, an aglycone of liquiritin in Glycyrrhizae radix, prevents acute liver injuries in rats induced by acetaminophen with or without buthionine sulfoximine. Chem. Biol. Interact. 2006, 161, 125-138. [CrossRef]

151. Fu, Y.; Chen, J.; Li, Y.-J.; Zheng, Y.-F.; Li, P. Antioxidant and anti-inflammatory activities of six flavonoids separated from licorice. Food Chem. 2013, 141, 1063-1071. [CrossRef] [PubMed] 
152. Yao, L.; Sun, T. Glycyrrhizin administration ameliorates Streptococcus aureus-induced acute lung injury. Int. Immunopharmacol. 2019, 70, 504-511. [CrossRef] [PubMed]

153. Yu, Z.; Ohtaki, Y.; Kai, K.; Sasano, T.; Shimauchi, H.; Yokochi, T.; Takada, H.; Sugawara, S.; Kumagai, K.; Endo, Y. Critical roles of platelets in lipopolysaccharide-induced lethality: Effects of glycyrrhizin and possible strategy for acute respiratory distress syndrome. Int. Immunopharmacol. 2005, 5, 571-580. [CrossRef] [PubMed]

154. Menegazzi, M.; di Paola, R.; Mazzon, E.; Genovese, T.; Crisafulli, C.; Dalbosco, M.; Zou, Z.; Suzuki, H.; Cuzzocrea, S. Glycyrrhizin attenuates the development of carrageenan-induced lung injury in mice. Pharmacol. Res. 2008, 58, 22-31. [CrossRef] [PubMed]

155. Xie, C.; Li, X.; Wu, J.; Liang, Z.; Deng, F.; Xie, W.; Zhu, M.; Zhu, J.; Zhu, W.; Geng, S.; et al. Anti-inflammatory activity of magnesium isoglycyrrhizinate through inhibition of phospholipase A2/Arachidonic acid pathway. Inflammation 2015, 38, 1639-1648. [CrossRef] [PubMed]

156. Bhattacharjee, S.; Bhattacharjee, A.; Majumder, S.; Majumdar, S.B. Glycyrrhizic acid suppresses Cox-2-mediated anti-inflammatory responses during Leishmania donovani infection. J. Antimicrob. Chemother. 2012, 67, 1905-1914. [CrossRef] [PubMed]

157. La, V.D.; Tanabe, S.-I.; Bergeron, C.; Gafner, S.; Grenier, D. Modulation of Matrix Metalloproteinase and Cytokine Production by Licorice Isolates Licoricidin and Licorisoflavan A: Potential Therapeutic Approach for Periodontitis. J. Periodontol. 2011, 82, 122-128. [CrossRef]

158. Kim, H.J.; Seo, J.-Y.; Suh, H.-J.; Lim, S.S.; Kim, J.-S. Antioxidant activities of licorice-derived prenylflavonoids. Nutr. Res. Pract. 2012, 6, 491-498. [CrossRef]

159. Thiyagarajan, P.; Chandrasekaran, C.V.; Deepak, H.B.; Agarwal, A. Modulation of lipopolysaccharide-induced pro-inflammatory mediators by an extract of Glycyrrhiza glabra and its phytoconstituents. Inflammopharmacology 2011, 19, 235-241. [CrossRef] [PubMed]

160. Ni, Y.-F.; Kuai, J.-K.; Lu, Z.-F.; Yang, G.-D.; Fu, H.-Y.; Wang, J.; Tian, F.; Yan, X.-L.; Zhao, Y.-C.; Wang, Y.-J.; et al. Glycyrrhizin Treatment Is Associated with Attenuation of Lipopolysaccharide-Induced Acute Lung Injury by Inhibiting Cyclooxygenase-2 and Inducible Nitric Oxide Synthase Expression. J. Surg. Res. 2011, 165, e29-e35. [CrossRef] [PubMed]

161. Cui, Y.; Ao, M.; Hu, J.; Yu, L. Anti-Inflammatory Activity of Licochalcone A Isolated from Glycyrrhiza inflata. Zeitschrift für Naturforschung C 2008, 63, 361-365. [CrossRef] [PubMed]

162. Acharya, S.K.; Dasarathy, S.; Tandon, A.; Joshi, Y.K.; Tandon, B.N. A preliminary open trial on interferon stimulator (SNMC) derived from Glycyrrhiza glabra in the treatment of subacute hepatic failure. Indian J. Med. Res. 1993, 98, 69-74. [CrossRef]

163. Seo, E.-H.; Song, G.-Y.; Kwak, B.O.; Oh, C.-S.; Lee, S.H.; Kim, S.-H. Effects of Glycyrrhizin on the Differentiation of Myeloid Cells of the Heart and Lungs in Lipopolysaccharide-Induced Septic Mice. Shock 2017, 48, 371-376. [CrossRef] [PubMed]

164. Edwards, C.R.; Benediktsson, R.; Lindsay, R.; Seckl, J.R. 11ß-Hydroxysteroid dehydrogenases: Key enzymes in determining tissue-specific glucocorticoid effects. Steroids 1996, 61, 263-269. [CrossRef]

165. Kao, T.-C.; Shyu, M.-H.; Yen, G.-C. Glycyrrhizic Acid and 18ß-Glycyrrhetinic Acid Inhibit Inflammation via PI3K/Akt/GSK3 $\beta$ Signaling and Glucocorticoid Receptor Activation. J. Agric. Food Chem. 2010, 58, 8623-8629. [CrossRef] [PubMed]

166. Ma, X.; Lian, Q.-Q.; Dong, Q.; Ge, R.-S. Environmental inhibitors of 11ß-hydroxysteroid dehydrogenase type 2. Toxicology 2011, 285, 83-89. [CrossRef] [PubMed]

167. Kao, T.-C.; Wu, C.-H.; Yen, G.-C. Glycyrrhizic acid and 18ß-glycyrrhetinic acid recover glucocorticoid resistance via PI3K-induced AP1, CRE and NFAT activation. Phytomedicine 2013, 20, 295-302. [CrossRef]

168. Mollica, L.; De Marchis, F.; Spitaleri, A.; Dallacosta, C.; Pennacchini, D.; Zamai, M.; Agresti, A.; Trisciuoglio, L.; Musco, G.; Bianchi, M.E. Glycyrrhizin Binds to High-Mobility Group Box 1 Protein and Inhibits Its Cytokine Activities. Chem. Biol. 2007, 14, 431-441. [CrossRef] [PubMed]

169. Bodet, C.; La, V.D.; Gafner, S.; Bergeron, C.; Grenier, D. A Licorice Extract Reduces Lipopolysaccharide-Induced Proinflammatory Cytokine Secretion by Macrophages and Whole Blood. J. Periodontol. 2008, 79, 1752-1761. [CrossRef] [PubMed]

170. Michaelis, M.; Geiler, J.; Naczk, P.; Sithisarn, P.; Leutz, A.; Doerr, H.W.; Cinatl, J. Glycyrrhizin Exerts Antioxidative Effects in H5N1 Influenza A Virus-Infected Cells and Inhibits Virus Replication and Pro-Inflammatory Gene Expression. PLoS ONE 2011, 6, e19705. [CrossRef]

171. Suzuki, M.; Tetsuka, T.; Yoshida, S.; Watanabe, N.; Kobayashi, M.; Matsui, N.; Okamoto, T. The role of p38 mitogen-activated protein kinase in IL-6 and IL-8 production from the TNF- $\alpha$ - or IL-1 $\beta$-stimulated rheumatoid synovial fibroblasts. FEBS Lett. 2000, 465, 23-27. [CrossRef]

172. Haworth, C.; Brennan, F.M.; Chantry, D.; Turner, M.; Maini, R.N.; Feldmann, M. Expression of granulocyte-macrophage colonystimulating factor in rheumatoid arthritis: Regulation by tumor necrosis factor- $\alpha$. Eur. J. Immunol. 1991, 21, 2575-2579. [CrossRef] [PubMed]

173. Jeong, S.-J.; Lim, H.-S.; Seo, C.-S.; Kim, J.-H.; Jin, S.-E.; Yoo, S.-R.; Shin, H.-K. Traditional herbal formula Jakyakgamcho-tang (Paeonia lactiflora and Glycyrrhiza uralensis) impairs inflammatory chemokine production by inhibiting activation of STAT1 and NF-kB in HaCaT cells. Phytomedicine 2015, 22, 326-332. [CrossRef] [PubMed]

174. Nagy, G.; Clark, J.M.; Buzas, E.; Gorman, C.; Pasztoi, M.; Koncz, A.; Falus, A.; Cope, A. Nitric oxide production of T lymphocytes is increased in rheumatoid arthritis. Immunol. Lett. 2008, 118, 55-58. [CrossRef] [PubMed]

175. Gumpricht, E.; Dahl, R.; Devereaux, M.W.; Sokol, R.J. Licorice compounds glycyrrhizin and 18beta-glycyrrhetinic acid are potent modulators of bile acid-induced cytotoxicity in rat hepatocytes. J. Biol. Chem. 2005, 280, 10556-10563. [CrossRef] 
176. Manns, M.P.; Wedemeyer, H.; Singer, A.; Khomutjanskaja, N.; Dienes, H.P.; Roskams, T.; Goldin, R.; Hehnke, U.; Inoue, H.; The European SNMC Study Group. Glycyrrhizin in patients who failed previous interferon alpha-based therapies: Biochemical and histological effects after 52 weeks. J. Viral Hepat. 2012, 19, 537-546. [CrossRef]

177. Li, J.-Y.; Cao, H.-Y.; Liu, P.; Cheng, G.-H.; Sun, M.-Y. Glycyrrhizic Acid in the Treatment of Liver Diseases: Literature Review. BioMed Res. Int. 2014, 2014, 872139. [CrossRef]

178. Ye, S.; Zhu, Y.; Ming, Y.; She, X.; Liu, H.; Ye, Q. Glycyrrhizin protects mice against renal ischemia-reperfusion injury through inhibition of apoptosis and inflammation by downregulating p38 mitogen-activated protein kinase signaling. Exp. Ther. Med. 2014, 7, 1247-1252. [CrossRef] [PubMed]

179. Zhang, Q.; Xiao, Z.; He, F.; Zou, J.; Wu, S.; Liu, Z. MicroRNAs Regulate the Pathogenesis of CVB3-Induced Viral Myocarditis. Intervirology 2013, 56, 104-113. [CrossRef] [PubMed]

180. Fujisawa, Y.; Sakamoto, M.; Matsushita, M.; Fujita, T.; Nishioka, K. Glycyrrhizin Inhibits the Lytic Pathway of ComplementPossible Mechanism of Its Anti-Inflammatory Effect on Liver Cells in Viral Hepatitis. Microbiol. Immunol. 2000, 44, 799-804. [CrossRef] [PubMed]

181. Kim, K.R.; Jeong, C.-K.; Park, K.-K.; Choi, J.; Park, J.H.Y.; Lim, S.S.; Chung, W.-Y. Anti-Inflammatory Effects of Licorice and Roasted Licorice Extracts on TPA-Induced Acute Inflammation and Collagen-Induced Arthritis in Mice. J. Biomed. Biotechnol. 2010, 2010, 709378. [CrossRef]

182. Mizgerd, J.P.; Spieker, M.R.; Doerschuk, C.M. Early response cytokines and innate immunity: Essential roles for TNF receptor 1 and type I IL-1 receptor during Escherichia coli pneumonia in mice. J. Immunol. 2001, 166, 4042-4048. [CrossRef] [PubMed]

183. Lauzurica, P.; Martínez-Martínez, S.; Marazuela, M.; del Arco, P.G.; Martínez-A, C.; Sánchez-Madrid, F.; Redondo, J.M. Pyrrolidine dithiocarbamate protects mice from lethal shock induced by LPS or TNF- $\alpha$. Eur. J. Immunol. 1999, 29, 1890-1900. [CrossRef]

184. Chu, X.; Ci, X.; Wei, M.; Yang, X.; Cao, Q.; Guan, M.; Li, H.; Deng, Y.; Feng, H.; Deng, X. Licochalcone A Inhibits Lipopolysaccharide-Induced Inflammatory Response in Vitro and in Vivo. J. Agric. Food Chem. 2012, 60, 3947-3954. [CrossRef]

185. Levine, B.; Deretic, V. Unveiling the roles of autophagy in innate and adaptive immunity. Nat. Rev. Immunol. 2007, 7, 767-777. [CrossRef]

186. Leib, D.A.; Alexander, D.E.; Cox, D.; Yin, J.; Ferguson, T.A. Interaction of ICP34.5 with Beclin 1 Modulates Herpes Simplex Virus Type 1 Pathogenesis through Control of CD4 + T-Cell Responses. J. Virol. 2009, 83, 12164-12171. [CrossRef] [PubMed]

187. Gassen, N.C.; Niemeyer, D.; Muth, D.; Corman, V.M.; Martinelli, S.; Gassen, A.; Hafner, K.; Papies, J.; Mösbauer, K.; Zellner, A.; et al. SKP2 attenuates autophagy through Beclin1-ubiquitination and its inhibition reduces MERS-Coronavirus infection. Nat. Commun. 2019, 10, 5770. [CrossRef] [PubMed]

188. Shojaei, S.; Suresh, M.; Klionsky, D.J.; Labouta, H.I.; Ghavami, S. Autophagy and SARS-CoV-2 infection: A possible smart targeting of the autophagy pathway. Virulence 2020, 11, 805-810. [CrossRef] [PubMed]

189. Tang, Z.-H.; Li, T.; Tong, Y.-G.; Chen, X.-J.; Chen, X.-P.; Wang, Y.-T.; Lu, J. A Systematic Review of the Anticancer Properties of Compounds Isolated from Licorice (Gancao). Planta Medica 2015, 81, 1670-1687. [CrossRef] [PubMed]

190. Vlaisavljevic, S.; Šibul, F.; Sinka, I.; Zupko, I.; Ocsovszki, I.; Jovanović-Šanta, S. Chemical composition, antioxidant and anticancer activity of licorice from Fruska Gora locality. Ind. Crops Prod. 2018, 112, 217-224. [CrossRef]

191. Glavač, N.K.; Kreft, S. Excretion profile of glycyrrhizin metabolite in human urine. Food Chem. 2012, 131, 305-308. [CrossRef]

192. Egashira, T.; Takayama, F.; Yufu, F.; Shoyama, Y. Pharmacokinetics of glycyrrhizin and glycyrrhetic acid following glycyrrhizin administration to rats with single and multiple doses via different routes. Jpn. Pharmacol. Ther. 2003, 31, 75-83.

193. Bai, H.; Bao, F.; Fan, X.; Han, S.; Zheng, W.; Sun, L.; Yan, N.; Du, H.; Zhao, H.; Yang, Z. Metabolomics study of different parts of licorice from different geographical origins and their anti-inflammatory activities. J. Sep. Sci. 2020, 43, 1593-1602. [CrossRef] [PubMed]

194. Tanaka, S.; Sakata, Y.; Morimoto, K.; Tambe, Y.; Watanabe, Y.; Honda, G.; Tabata, M.; Oshima, T.; Masuda, T.; Umezawa, T.; et al. Influence of Natural and Synthetic Compounds on Cell Surface Expression of Cell Adhesion Molecules, ICAM-1 and VCAM-1. Planta Medica 2001, 67, 108-113. [CrossRef]

195. Shi, C.-C.; Chen, T.-R.; Zhang, Q.-H.; Wei, L.-H.; Huang, C.; Zhu, Y.-D.; Liu, H.-B.; Bai, Y.-K.; Wang, F.-J.; Guo, W.-Z.; et al. Inhibition of human thrombin by the constituents of licorice: Inhibition kinetics and mechanistic insights through in vitro and in silico studies. RSC Adv. 2020, 10, 3626-3635. [CrossRef]

196. Guan, W.-J.; Ni, Z.-Y.; Hu, Y.; Liang, W.-H.; Ou, C.-Q.; He, J.-X.; Liu, L.; Shan, H.; Lei, C.-L.; Hui, D.S.C.; et al. Clinical Characteristics of Coronavirus Disease 2019 in China. N. Engl. J. Med. 2020, 382, 1708-1720. [CrossRef] [PubMed]

197. Chen, H.; Du, Q. Potential natural compounds for preventing SARS-CoV-2 (2019-nCoV) infection. Preprints 2020, 2020010358. [CrossRef]

198. Cosmetic Ingredient Review Expert Panel. Final Report on the Safety Assessment of Glycyrrhetinic Acid, Potassium Glycyrrhetinate, Disodium Succinoyl Glycyrrhetinate, Glyceryl Glycyrrhetinate, Glycyrrhetinyl Stearate, Stearyl Glycyrrhetinate, Glycyrrhizic Acid, Ammonium Glycyrrhizate, Dipotassium Glycyrrhizate, Disodium Glycyrrhizate, Trisodium Glycyrrhizate, Methyl Glycyrrhizate, and Potassium Glycyrrhizinate1. Int. J. Toxicol. 2007, 26 (Suppl. 2), 79-112. [CrossRef]

199. Chen, F.; Chan, K.H.; Jiang, Y.; Kao, R.Y.T.; Lu, H.T.; Fan, K.W.; Cheng, V.C.C.; Tsui, W.H.W.; Hung, I.F.N.; Lee, T.S.W. In vitro susceptibility of 10 clinical isolates of SARS coronavirus to selected antiviral compounds. J. Clin. Virol. 2004, 31, 69-75. [CrossRef] 
200. Ruiz-Granados, E.S.; Shouls, G.; Sainsbury, C.; Antonios, T. A salty cause of severe hypertension. BMJ Case Rep. 2012, 2012, bcr1220115336. [CrossRef] [PubMed]

201. Mu, Y.; Zhang, J.; Zhang, S.; Zhou, H.-H.; Toma, D.; Ren, S.; Huang, L.; Yaramus, M.; Baum, A.; Venkataramanan, R.; et al. Traditional Chinese Medicines Wu Wei Zi (Schisandra chinensis Baill) and Gan Cao (Glycyrrhiza uralensis Fisch) Activate Pregnane $X$ Receptor and Increase Warfarin Clearance in Rats. J. Pharmacol. Exp. Ther. 2005, 316, 1369-1377. [CrossRef] [PubMed]

202. Cavallari, L.H.; Limdi, N.A. Warfarin pharmacogenomics. Curr. Opin. Mol. Ther. 2009, 11, 243-251. [PubMed] 